\title{
Quantitative and Qualitative Assessment of Soil Erosion Risk in Małopolska (Poland), Supported by an Object-Based Analysis of High-Resolution Satellite Images
}

\author{
Wojciech Drzewiecki, ${ }^{1}$ Piotr WèżK, ${ }^{2}$ Marcin Pierzchalski, ${ }^{3}$ and Beata Szafrańska ${ }^{1,4}$
}

\begin{abstract}
In 2011 the Marshal Office of Małopolska Voivodeship decided to evaluate the vulnerability of soils to water erosion for the entire region. The quantitative and qualitative assessment of the erosion risk for the soils of the Małopolska region was done based on the USLE approach. The special workflow of geoinformation technologies was used to fulfil this goal. A high-resolution soil map, together with rainfall data, a detailed digital elevation model and statistical information about areas sown with particular crops created the input information for erosion modelling in GIS environment. The satellite remote sensing technology and the object-based image analysis (OBIA) approach gave valuable support to this study. RapidEye satellite images were used to obtain the essential up-to-date data about land use and vegetation cover for the entire region $\left(15,000 \mathrm{~km}^{2}\right)$. The application of OBIA also led to defining the direction of field cultivation and the mapping of contour tillage areas. As a result, the spatially differentiated values of erosion control practice factor were used. Both, the potential and the actual soil erosion risk were assessed quantificatively and qualitatively. The results of the erosion assessment in the Małopolska Voivodeship reveal the fact that a majority of its agricultural lands is characterized by moderate or low erosion risk levels. However, high-resolution erosion risk maps show its substantial spatial diversity. According to our study, average or higher actual erosion intensity levels occur for $10.6 \%$ of agricultural land, i.e. $3.6 \%$ of the entire voivodeship area. In $20 \%$ of the municipalities there is a very urgent demand for erosion control. In the next $23 \%$ an urgent erosion control is needed. Our study showed that even a slight improvement of P-factor estimation may have an influence on modeling results. In our case, despite a marginal change of erosion assessment figures on a regional scale, the influence on the final prioritization of areas (municipalities) according to erosion control needs is visible. The study shows that,
\end{abstract}

1 AGH University of Science and Technology, Faculty of Mining Surveying and Environmental Engineering, Al. Mickiewicza 30, 30-059 Kraków, Poland. E-mail: drzewiec@agh.edu.pl

2 Department of Forest Ecology, Faculty of Forestry, Laboratory of Geomatics, Agricultural University in Krakow, Al. 29 Listopada 46, 31-425 Kraków, Poland.

3 ProGea Consulting, ul. Pachońskiego 9, 31-223 Kraków, Poland.

4 The Marshall Office of Małopolska Voivodeship, ul. Racławicka 56, 30-017 Kraków, Poland. high-resolution satellite imagery and OBIA may be efficiently used for P-factor mapping and thus contribute to a refined soil erosion risk assessment.

Key words: Soil erosion, Małopolska, USLE, OBIA, RapidEye, erosion control practice factor.

\section{Introduction and background}

Soil erosion, defined as the detachment of soil particles and their transport by wind or water, is a natural process driven by physical factors. The energy necessary for soil particle detachment and its transport is provided by wind or water (rain or surface runoff). However, if erosion processes occur, and how intensive they are, depends also on soil properties, topography, and vegetation cover.

In the case of soil erosion by water soil material can be detached by raindrops or flowing water. Raindrops hitting the surface have enough energy to throw the soil particles or small aggregates out into the air and scatter them around. The soil detachment rate increases rapidly with rainfall intensity (JONES et al. 2004). The share of raindrop erosion in the total erosion rate can be very important. It can even be the main erosion process on convex upper parts of slopes (Józefaciuk and Józefaciuk 1996). Additionally, soil particles detached and redeposited during this process fill the macropores. It results in a decrease of infiltration and an increase of surface runoff and, in turn, the erosion rate down to the slope. Even if the raindrops fall into a layer of surface water and do not detach the soil particles directly, they increase soil erosion, increasing the transport capacity of water as an effect of the increased turbulence (WARD and ELLIOT 1995). 
Soil particles detached by raindrops can be transported in all directions by the air (saltation) or downslope by the thin layer of flowing water. These processes (interrill erosion) are able to carry soil grains for a very limited distance (increasing with the slope gradient). They stay close to the place of their origin or can be transported further by surface runoff, causing rill erosion.

Runoff is considered as the most important direct driver of soil erosion (Jones et al. 2004). If the flow has enough power to detach the soil particles, small rills are formed along the flow lines influenced by the (micro)topography of the terrain. The sights of erosion visible in the field are almost entirely caused by rill erosion (LAFLEN and Roose 1998). The rate of rill erosion depends on the amount of runoff and is related to rainfall intensity, soil infiltration, and slope length.

Vegetation cover plays a very important role as a factor mitigating soil erosion by water. First of all, if rainfall is intercepted by a canopy, the impact of raindrops on soil erosion is much lower (JONES et al. 2004). Interception also decreases the amount of runoff. A vegetation canopy reduces the flow power as well as its transport capacity.

The natural process of soil erosion becomes a threat when the rate of erosion is significantly increased by human activity (JONES et al. 2004). Nowadays, soil erosion is considered the main reason for soil degradation in Europe (VAN LyNDEN 1995). Bork (2003) has investigated soil erosion processes in Europe from $1800 \mathrm{AD}$. His review is concluded with a statement that a significant increase of soil erosion in the 20th century occurred due to changes in the structure of the landscape and the intensification of agriculture. He pointed out that in Central Europe (including Poland) erosion rates tripled in the 1950-1970s as a result of increased crop field sizes and changes in agricultural practices.

In the Małopolska Voivodeship, soil erosion by water is considered the main factor leading to soil degradation. WAwER (2007) indicated that Małopolska is a region with the highest threat of soil erosion in Poland. According to his analysis, based on statewide studies of water erosion risk in Poland (WAWER and Nowocień 2007), as much as $27 \%$ of its total area is endangered by erosion which may lead to a total reduction of humus horizon or even a total destruction of the soil profile. In the second Polish region of this assessment, the percentage of endangered areas is almost half as much. The relief is considered as a main factor responsible for such high erosion risk in Małopolska (WAwER and NowociEN 2007; WAWER 2007). It should also be noted that the highest rainfall erosivity in Poland occurs in the south mountainous part of the region (LiczNAR 2006).

Protection from soil degradation forms the basis for sustainable development of countryside areas. In Poland both, regional land use planning and the coordination of agricultural policy in the region, are in the domain of Marshall Offices. These regional (voivodeship) authorities are responsible for the identification of the high risk areas of soil degradation as well as determining the needs for implementing land protection procedures or land reclamation. They should aim at preventing soil devastation and the transformation of highly fertile arable land into non-arable and non-forested areas.

The mapping of soil erosion risk was initiated by the Marshal Office as a useful instrument for regional soil conservation policy planning, as well as making citizens aware of the impact of their activities on the economic functions of the environment and the land. This initiative corresponds to the growing demand for soil erosion risk maps in Europe (Prasuhn et al. 2013).

Usually soil erosion risk maps are obtained based on erosion models (PrasuHn et al. 2013). When dealing with soil erosion modeling one can choose from several different approaches ranging from indicator-based ones to advanced process-based models. In Poland, the procedure proposed by JózEFACIUK and JózEFACIUK (1992) has been widely used for the assessment of soil erosion risk on a regional scale. In this indicator-based approach, the potential (i.e., irrespective of current land use and vegetation cover) water erosion hazard is estimated on the basis of soil type, slope classes, and the amount of annual precipitation. Actual erosion risk can also be assessed when aspects such as land use, size and shape of plots, or the tillage system are taken into consideration (for details see, e.g., WAWER and Nowocień 2007). As a result, one can obtain spatial pattern of erosion risk, but only in a qualitative manner-in the form of erosion hazard classes. 
This methodology was applied in statewide studies, both for potential (JózEFACIUK and JózEFACIUK 1996; WAWER et al. 2006) and actual (WAWER and Nowocień 2006; WAWER and Nowocień 2007) erosion risk assessment. However, these studies were based on data with a low level of spatial detail (e.g., soil map in a scale of 1:300000 or land use from the CORINE Land Cover database corresponding to a scale of 1:100000). Moreover, the assessment results were quite different for different input data sets used in particular studies.

In Małopolska, due to the physiographic diversity of the region, the need for high-resolution assessments of soil erosion risk were needed with a level of detail enabling identification of the most endangered areas within the voivodeship; where soil erosion may become an important economical and environmental problem. As none of the available national level erosion assessments satisfied the needs, a new one (in the regional scale) was necessary. The study has also been intended as a tool for arranging the municipalities in Małopolska according to the urgency of implementation of erosion control measures. Such prioritization was required for the development of a regional agricultural policy and the judicious allocation of limited resources.

When the goals of the undertaken project were discussed, it was stressed that apart from the qualitative assessment of soil erosion risk, the quantitative estimation of soil loss due to water erosion should be considered. Consequently, the USLE-based modeling approach was selected as the soil erosion risk assessment tool in the reported project. Undoubtedly, the Universal Soil Loss Equation (USLE, WISCHMEIER and SмIтH 1978) and its revised version-RUSLE (RENARD et al. 1997) are the best known soil erosion modeling tools in the world. The model proves its usefulness in different environments and is not datademanding compared with others, especially the process-based erosion models. Although the USLE was originally developed for the assessment of soil loss due to sheet and rill erosion on the scale of an agricultural plot, it is possible to apply it, with some modifications, on the catchment or regional scales (Cebecauer and Hofierka 2008; Chen et al. 2011). It has been used for erosion risk assessment in many European countries as well as for European-wide studies (Jones et al. 2004). USLE/RUSLE based high-resolution erosion risk maps for entire regions, and even countries, are also available (e.g., PrasuHn et al. 2013; TetzlafF et al. 2013; MarTín-FernÁNDEZ and MARTínEZ-NúŇEZ 2011; PARK et al. 2011; Deumlich et al. 2006). In Poland, this approach has never been applied as a tool of regional high-resolution assessment for soil erosion risks.

In USLE, the mean annual soil loss (actual erosion rate) is calculated with the Eq. (1):

$$
E_{A}=R K L S C P
$$

where $E_{A}$ is the mean annual soil erosion rate (actual erosion rate) $\left(\mathrm{t} \mathrm{ha}^{-1} \mathrm{y}^{-1}\right), R$ is the rainfall erosivity factor $\left(\mathrm{MJ} \mathrm{mm} \mathrm{ha}{ }^{-1} \mathrm{~h}^{-1} \mathrm{y}^{-1}\right), K$ is the soil erodibility factor ( $\mathrm{t} \mathrm{h} \mathrm{MJ}^{-1} \mathrm{~mm}^{-1}$ ), $L S$ is the topographic factor (dimensionless), $C$ is the cover management factor (dimensionless), $P$ is the erosion control practice factor (dimensionless).

The formula can also be used for the estimation of the potential erosion rate, i.e. the erosion rate from the black fallow without any erosion control practices. In such a case the equation abbreviates to:

$$
E_{P}=R K L S
$$

where $E_{P}$ is the mean annual soil erosion rate (potential erosion rate) $\left(\mathrm{t} \mathrm{ha}^{-1} \mathrm{y}^{-1}\right)$.

The high-resolution mapping of potential erosion risk in Małopolska was feasible as detailed terrain and soil data for the entire area of the region have been available. It was also assumed that the rainfall erosivity can be estimated with accuracy that is satisfactory. Unfortunately, a reliable assessment of actual erosion risk was impossible as essential data about land use and vegetation cover, as well as management practices on agricultural lands were unavailable. The CORINE Land Cover database was identified as the only source of up-to-date land use data covering the whole Małopolska region. However, its level of accuracy is far too low to enable detailed soil erosion risk assessment. No digital spatial data on agricultural management practices were found.

A review of the regional erosion studies show that similar problems were faced in other countries as well. Only TetzlafF et al. (2013) in their evaluation done for the region of Hesse (Germany) were able to 
use C-factor values based on field-level crop type information available for the entire state (ca. 655,000 parcels).

Prashun et al. (2013) assessed the erosion risk in Switzerland on a very detailed scale (plot level, $2 \times 2 \mathrm{~m}$ grid). The assessment was limited to the potential erosion as no data for current land use and cultivation were available on the plot level. TERRANOVA et al. (2009) based their evaluation in the Calabria region (Italy) on Corine Land Cover data, but reprocessed and detailed to a 1:25000 scale. In Slovakia, Cebecauer and Hofierka (2008) also based their studies on the CLC map, but for agricultural categories the $\mathrm{C}$-factor was calculated as a weighted average of the mean annual values of $\mathrm{C}$-factor for the main crops in the particular districts taken from statistical data. A similar approach was adopted earlier in Slovakia by Š́́ri et al. (2002) and by ERHARD et al. (2003) in Germany. Deumlich et al. (2006) in their study for Branderburg (Germany) used the same C-value calculated as an average for the entire region.

In all the mentioned examples the actual erosion rates were calculated with a P-factor value equal to 1 , assuming no erosion control management practices were in place. Other approaches are presented by Martín-FernándeZ and MartínEZ-NúŇEZ (2011) and PARK et al. (2011). The first ones calculated the spatially differentiated values of $\mathrm{C}$ - and P-factors based on stratified sampling. PARK et al. (2011) ascribed these values to particular categories on the land use map.

To satisfy the project needs and time restrictions we decided to base the evaluation of $\mathrm{C}$ - and P-factors on satellite remote sensing images. An extensive review of satellite remote sensing applications for the assessment of water erosion is given by VRIELING (2006). Additionally, Zhang et al. (2011) provide a review focused on USLE cover and management factor estimation using satellite imagery. Satellite technology is seen as a valuable tool for vegetation cover mapping. Land use classification followed by assigning C-factor values to particular mapped categories is mentioned as an approach often used. However, applications of high-resolution satellite imagery in regional scale assessments have not been reported. Other remote sensing based approaches to $\mathrm{C}$-factor estimation include linear regression between image bands or ratios and $\mathrm{C}$-factor values determined in the field, usage of spectral vegetation indices, or estimation of vegetation coverage through sub-pixel classification methods. Spectral unmixing was applied by Lu et al. (2004) in the study of erosion risk in the Rondonia region (Brazil). Regression formulas are not transferable to regions with different environmental conditions. Methods based on sub-pixel estimation of vegetation fraction should be based on multitemporal images to reflect changes due to plant phenology.

In the case of USLE support (conservation) practice factor usage of satellite remote sensing is rather limited. According to VRIELING (2006), many conservation measures can be easily detected on aerial photographs, but the usage of satellite images is quite rare. Detection of conservation tillage practices seems to be the only exception; it is possible because of differences caused by tillage practices in surface roughness and crop residuals' coverage. In some studies P-factor values have been assigned to land use classes derived from a classification of satellite imagery (PRASANNAKUMAR et al. 2011), assuming that some practices commonly occur within a given land use category in the studied region.

New opportunities for the application of satellite remote sensing for the detection of conservation practices have arisen due to the increased spatial resolution of satellite imagery and the object-based image analysis methodology. Tindall et al. (2008) used high-resolution SPOT images $(2.5 \mathrm{~m})$ and the OBIA approach successfully for the detection and mapping of terraces in Queensland (Australia). They concluded their study with a statement that despite some limitations OBIA has great potential for selected land management practice mapping. KARYDAS et al. (2009) applied OBIA to QuickBird images to map terraces as well as rural roads lying across the slope direction at the test site (6,800 ha) in Crete, Greece. They compared the results of the RUSLEbased soil erosion risk assessment with uniform $\mathrm{P}$-factor value and P-factor value spatially differentiated based on satellite image classification results. Differences in erosion risk evaluation important from an operational and planning point of view were noticed for $3 \%$ of the total studied area. However, they suggest that using high resolution satellite 
imagery for mapping the P-factor value enables refinement of soil erosion modeling and allows for field level soil erosion risk mapping.

The following goals were formulated for the project carried out in the Małopolska region: (i) to obtain a high-resolution land use map for the entire region based on an object-oriented analysis of high-resolution satellite imagery; (ii) to evaluate the quantitative and qualitative potential and actual soil erosion risk in the region, based on the USLE approach; (iii) to prioritize the administrative units (municipalities) according to erosion control urgency levels.

In our study we assumed that object-based image analysis would allow not only detailed land use mapping but also for the delimitation of areas where contour tillage takes place. Taking this practice into account when calculating P-factor values should be a step forward to more reliable high-resolution erosion risk modeling. The application of an object-based analysis of high-resolution satellite images to assess the $\mathrm{C}$-factor values on a regional scale, as well as to detect contouring, have not been reported in literature so far. In our opinion, it is undoubtedly a new quality in this type of research, resulting in better-founded prioritization of the areas for erosion control practices.

The main objectives of this paper are as follows: (i) to give an overview of the USLE-based highresolution regional scale erosion risk modeling approach, which has been adopted for the prioritization of administrative units according to erosion control urgency; (ii) to assess the usefulness of OBIA of high-resolution satellite images for regional-scale land use mapping and evaluation of chosen USLE factors; (iii) to evaluate the influence of including contour tillage areas in P-factor value estimation on erosion modeling results and prioritization of the municipalities according to erosion control urgency levels.

\section{Study Area}

The Małopolska Voivodeship (Fig. 1) presents a variety of landforms, geological and hydrological conditions, weather and soils. This region has the biggest physiographical diversity in Poland. It is the result of a wide range of land elevation from $130 \mathrm{~m}$ above sea level to Mount Rysy, the highest peak in Poland at an elevation of 2,499 m. Małopolska Upland (200-300 m) covers the northern part of the region. The Sandomierz basin $(135 \mathrm{~m})$ is situated within the Vistula river gorge in the north-eastern part of the province. It is an extensive tectonic hollow processed by river erosion. The Carpathian range covers the southern part of the Małopolska region with the highest mountain range in Poland - the Tatras.

The annual rainfall in the area varies from $550 \mathrm{~mm}$ in Małopolska Upland to 1,200-1,400 mm in the Carpathian Mountains. In general, the amount of rainfall decreases from the west to the east, with the highest mean figures in the months of June and July (150-200 $\mathrm{mm}$ in the mountains and 70-120 mm

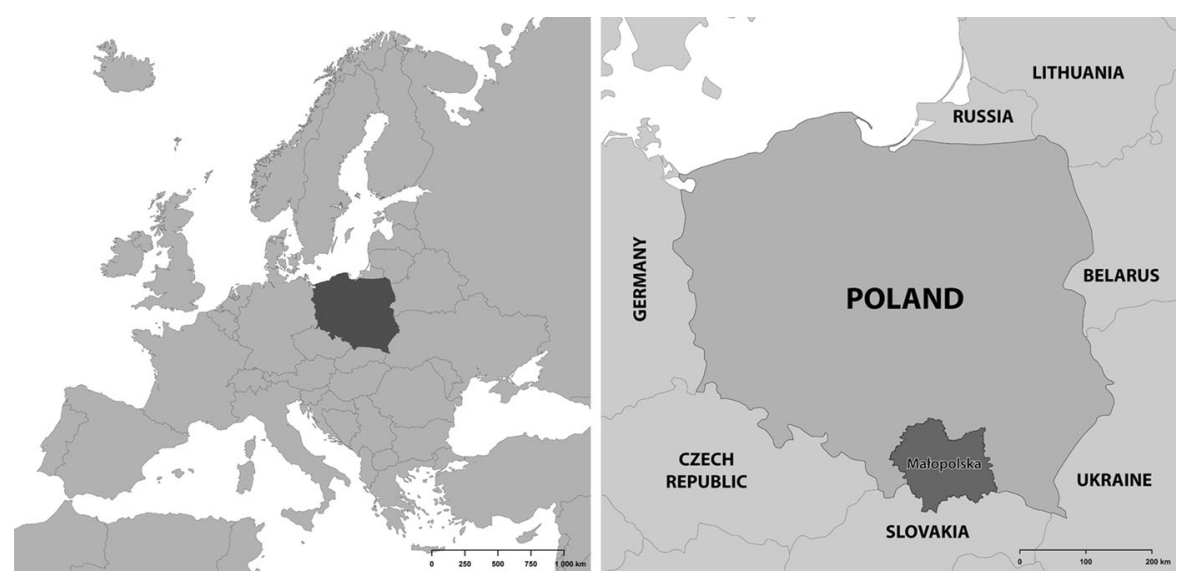

Figure 1

Location of the studied area 
over the rest of the area) and the lowest between January and March. Snow cover depends on the elevation and form of the land. In Małopolska Upland the snow cover remains from 60 to 80 days on average; in the Carpathians from 80 to 200 days; in the Tatras (Mount Kasprowy) 231 days.

The population of Małopolska is about 8500,000 people with a population density of 140 people per square kilometer.

Arable areas prevail in the land use of the voivodeship. In 2003, they covered 749,000 ha, i.e. $49.3 \%$ of the region's overall surface and $4.6 \%$ of Poland's arable land. This land use is divided between fields (65\%), orchards (1.8\%), and pastures $(33.3 \%)$. Eastern and northern parts of the region, along with the north of the Carpathian foothills, provide the best soil conditions for food production. However, in recent years there can be observed a continuous decrease in arable land and there are also more pastures which are replacing fields.

High quality soils prevail in Małopolska. According to the soil valuation, the best soil classes appear in the northern and central parts of the area. The south has poorer soil types but, in spite of this fact, good conditions exist for organic food production thanks to the pollution-free environment.

The Małopolska region experiences extreme weather conditions. There are periods of excessive rainfall and floods on the one hand, but water deficiency and droughts on the other. The voivodeship

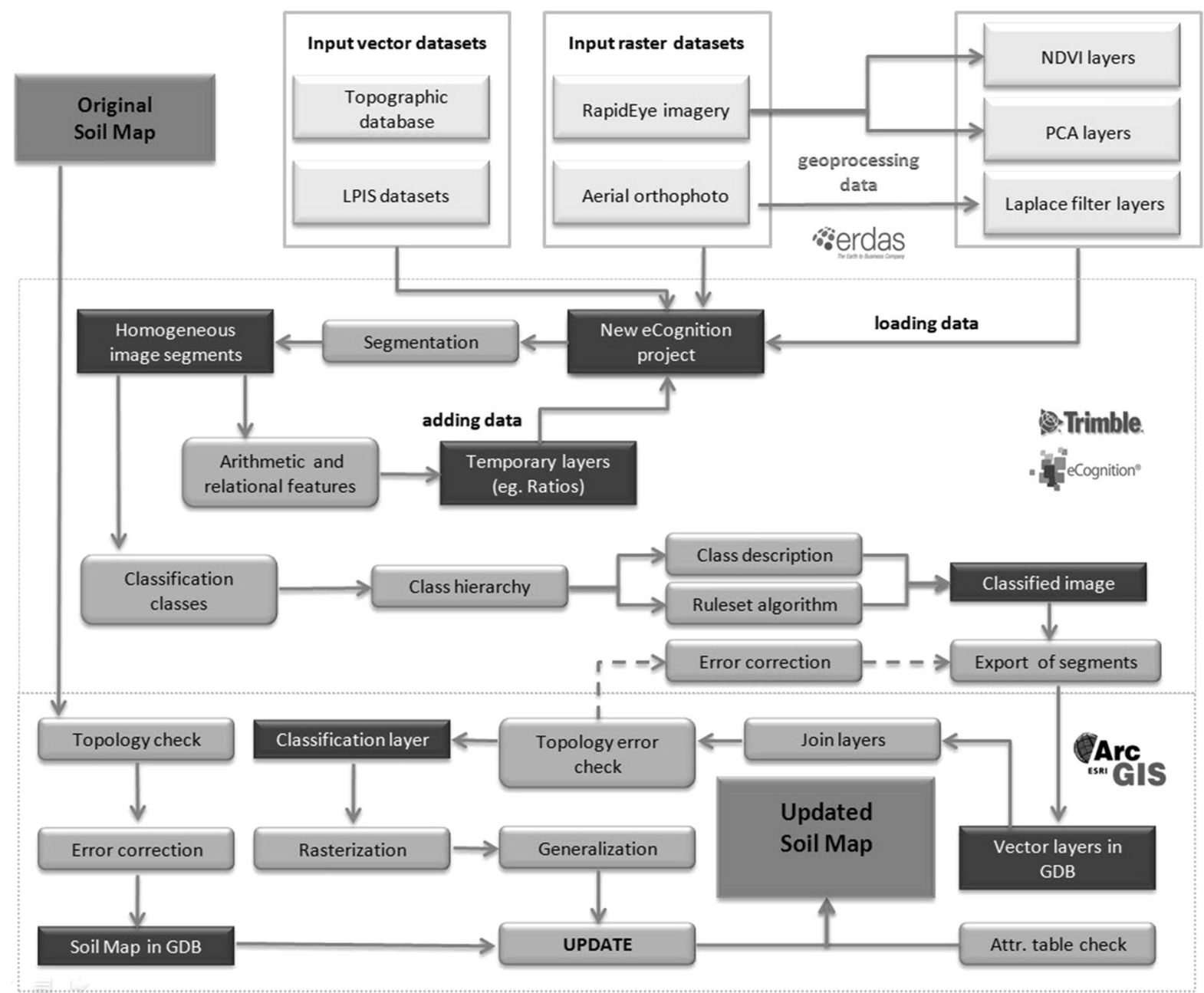

Figure 2

Update process of digital soil map with LULC information 
has the highest amount of rainfall in Poland and the highest risk of floods ( $15 \%$ higher than the rest of Poland).

Gullies appear on $53 \%$ of the area. Although the medium gully erosion applies only to $25 \%$ of the land, as much as $14 \%$ experience intensive and $1.5 \%$ very intensive erosion. The wind erosion risk in Małopolska is rather low and applies to only $0.1 \%$ of the area. Water erosion remains the main danger for soils in Małopolska.

\section{Materials and Methods}

\subsection{Materials}

The data used for the survey can be divided into two main categories according to their source: (i) data taken from existing spatial databases and (ii) data derived from remotely sensed imagery.

\subsubsection{Spatial Data}

Available source data comprised of:

- Soil map-vector data set from the Survey Office, digital version of a detailed (1:5000) soil map. The source map was created in the 1960s. Its information content can be divided into two main categories: soil characteristics and land use/land cover (LULC). As the soil's characteristics change very slowly, the soil-related information is considered reliable. However, LULC data had to be updated in the frame of the project (Fig. 2).

- Digital Terrain Model (DTM)-reference data set from the Survey Office, based on the photogrammetric workout in the form of a Triangulated Irregular Network (TIN) having a vertical accuracy to the tens of centimeters.

- Land Parcel Information System (LPIS) - vector data that represents property boundaries of land parcels (cadastral information) and their land use (2006). That layer was updated during the classification process.

- Topographical Database including the information about buildings and road layers. The vector layers were collected from the photo interpretation of aerial orthophotos (2009).
- Aerial orthophotomaps (RGB) of $0.25 \mathrm{~m}$ ground resolution (2009-10).

- Administrative unit boundaries-reference data set from the Survey Office.

- Meteorological data-monthly precipitation data for 92 locations in Małopolska from the years 1981-2009.

Before they were used for modeling purposes all spatial datasets were converted from vector to raster form with a cell size of $15 \mathrm{~m}$. In the case of the soil map, two different raster maps were created (one presenting the soil texture and the second with LULC data). DTM was additionally smoothed with a $5 \times 5$ Gaussian filter to decrease the impact of its errors (linear artifacts) on derivated slope and aspect maps as well as on the hydrological modeling results.

This set of spatial data was accompanied by statistical data about the areas sown with particular crops, at the municipality level, originated from the National Agricultural Census taken in 2002. Analogical data from the agricultural census taken in 2010 have been available only at a coarser level of the entire voivodeship and the group of crops.

\subsubsection{Satellite Remote Sensing Imagery}

Satellite remote sensing systems are characterized by a large variety of parameters, where the most commonly used is a spatial (ground) resolution (IFOV, GSD). This parameter is defined by a pixel size, can vary between dozens of meters (e.g., $80 \mathrm{~m}$ in the case of Landsat MSS) and submeter range (70 $\mathrm{cm}$ for Pléiades-panchromatic images or $0.5 \mathrm{~m}$ GeoEye-1). The next parameter of the satellite imaging systems is the spectral resolution-the range of electromagnetic radiation that can be recorded by a sensor mounted on a spacecraft. Spectral resolution is defined by the number of separate bands of registered electromagnetic waves at the same time (e.g., Landsat MSS: 4 bands; Landsat TM: 7 bands; IKONOS-2: 5 bands; RapidEye: 5 bands; ASTER: 15 bands). On the other hand radiometric resolution represents the number of brightness levels that can be obtained by a sensor (e.g. 8 bit by Landsat TM means 255 levels; RapidEye: 11 bit). The last, but not least, parameter is the time resolution. This parameter determines the 
satellite system revisit time of the same geographic location. For example, for RapidEye's satellite constellation, the time resolution is only 1 day, while for Landsat TM-16 days.

In this study, the RapidEye system has been chosen due to its very high time, spatial and spectral resolutions. RapidEye satellite remote sensing system is a constellation of five satellites moving at intervals of about 19 min on the same polar orbit. The system is characterized by high spatial (5.0 m GSD), spectral (5 channels, 400-800 nm, RGB $+2 \times$ NIR), radiometric (12 bit), and time (one day revisit time) resolution (KRISChKe et al. 2000; SANDAU et al. 2010). The RapidEye system having a $77 \mathrm{~km}$ wide strip within $24 \mathrm{~h}$ can collect up to 4 million sq. $\mathrm{km}$ from its $630 \mathrm{~km}$ height orbit.

A 1 day revisit time guarantees that a large area (such as a voivodeship) can be obtained in a short time (few days), which means large homogeneity of data (very important in object-based image analysis). Spectral resolution equal to $5.0 \mathrm{~m}$ (resampled from $6.5 \mathrm{~m}$ ) is compromised of the study area size and processing time. Higher resolution images would be almost impossible to analyze in such a large area $(15,000$ sq. $\mathrm{km})$ in the planned time period. The socalled "red edge" spectral band (690-730 nm) is a very unique enhancement of standard NIR range that can improve the analysis of vegetation.

There were 83 RapidEye satellite scenes used in the study. All of them were merged into 20 blocks of images according to their acquisition date. These image blocks were orthorectified using a strict orbital model. Then, orthoimages were additionally rectified using affine transformation based on ground control points acquired from aerial orthophotomaps. The positional accuracy of the rectified satellite images was assessed using check points measured on aerial orthophotomaps. Root mean square error $\left(\mathrm{RMS}_{\mathrm{XY}}\right)$ values calculated for particular blocks were in the range of $0.13-4.96 \mathrm{~m}$ and the average $\mathrm{RMS}_{\mathrm{XY}}$ value was equal to $2.37 \mathrm{~m}$.

\subsection{OBIA}

Mapping large areas covered with different land cover classes is possible through the means of various methods for classification of remote sensing imagery
(LiLlesand et al. 2007). These methods differ in many aspects, making some of them more suitable for processing large amounts of image data. So far, traditional methods were based on so-called "pixelby-pixel" image classification. Usually only spectral response (DN; digital number) of a single pixel in a chosen band was taken under consideration for statistical differentiation. Object-based image analysis (OBIA) is rather new and certainly a revolutionary approach to the image segmentation and classification process (BLASCHKE 2010). OBIA approach segments image into homogeneous regions (objects), that are the building blocks for further analysis, which can be automated using so-called "rule-sets" (DE KoK and WEżyK 2008). Individual image segments better reflect real world objects than separated from the context pixels based only on spectral values. Segmentation and classification algorithms are similar to manual vectorization done by a qualified operator (BEnz et al. 2004; ALdRed and Wang 2011). OBIA can be done on many connected levels that create a relational object structure. The main advantage of this type of classification are neighborhood functions that can be applied to image segments. These functions define spatial relations (such as 'distance to' or 'relative border to') that must be met to classify the object. Using the OBIA method, we can distinguish LULC classes impossible to separate using traditional pixel-based classification (e.g., clear cut area similar to arable land without vegetation).

Object-based image analysis was used based on the eCognition Developer (Trimble GeoSpatial) software. From the different segmentation methods, authors have chosen the Multiresolution Segmentation algorithm. This approach minimizes the average heterogeneity of the image objects and can perform both on a raw and previously segmented image. Segmentation parameters were developed by a trialand-error method: scale $=50$, shape $=0.5$, and compactness $=0.5$. The first division of the image was insufficient for the classification process because of wrongly created segments. The next segmentation algorithm (Spectral Difference Segmentation) merged neighboring image objects according to their mean intensity values. Maximum difference factor $=200$ was used for object creation. After the completion of the segmentation process, single classifiers were 
defined. Hierarchical class structure was created by merging particular classes into logical functional groups (e.g., 'Forest' class group included: 'deciduous forest', 'coniferous forest' and 'logging/clear cut'). To improve OBIA results, the additional derivative raster layers (principal component images and normalized difference vegetation index-NDVI) were generated based on the RapidEye images. To improve the recognition of urbanized areas, additional input data for object-based classification were obtained by applying a Laplace filter to aerial orthophotomaps (JELONEK and WyCZAłEK 2006). Because of a substantial difference in the ground resolution of digital aerial orthophotomaps and RapidEye satellite images $(0.25$ and $5.0 \mathrm{~m}$, respectively), aerial images were resampled to a $2.5-\mathrm{m}$ pixel size.

Many LULC classes were determined with the help of a "neighborhood" dependence. As a result of completing and implementing all classification rules, the final classification of the segments took place. To perform a further GIS analysis, results from the OBIA were exported to a vector format (ESRI shapefile). The classification accuracy was assessed by comparing a random located set of test points. For each test point the classification result was compared to the class described by the manual image interpretation. The overall accuracy of the final product was estimated at a level of $88 \%$.

The actual LULC map, based on the newest RapidEye satellite imagery, was exported from the eCognition software and, together with the GIS layers from the reference topographic database, were used in the process of the digital soil map update. It needs to be mentioned that Polish digital soil maps provide information about the soils for agricultural lands only. Other land types, e.g., urban areas or forests, are presented on the map, but without soil characteristics.
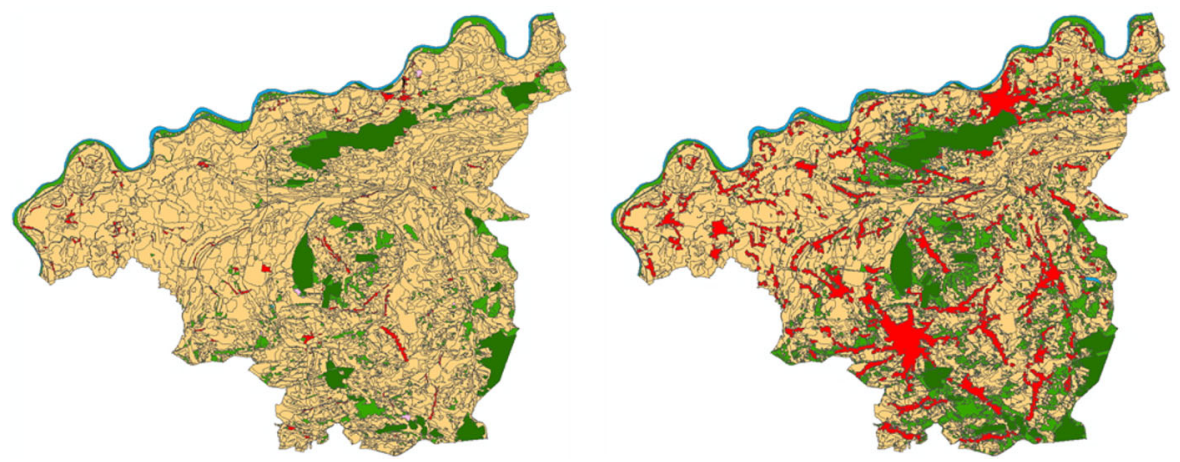

Figure 3

Original and updated soil maps—district view (red urban areas, green forests, beige agriculture areas)
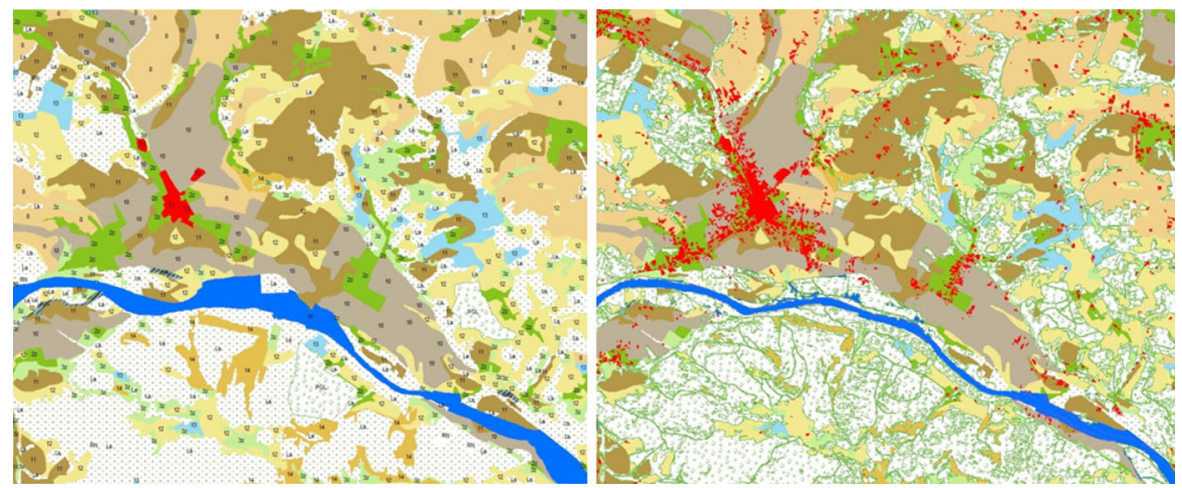

Figure 4

Original and updated soil maps-detailed view (red urban areas, green forests, beige agriculture areas) 
The term 'update' refers in this case to a modification of the geometry and the attributes of selected LULC classes, rather than soil type attribute changes.

The update of the soil map was done separately for each LULC class. For example, the 'developed area' class layer obtained from OBIA was merged with buildings taken from the reference Topographical Database. Then, after a generalization of the borders, polygons with areas less than 0.5 ha were removed (regarding GUGIK 2008). After the polygons of the digital soil map were updated, the layers were checked for topological and attribute errors. Finally, the new digital soil map was processed cartographically. Figures 3 and 4 present parts of the map before and after the update.

\subsection{Erosion Modeling}

Values of every factor from the (R)USLE Eq. (1) should be calculated according to the rules described in the manual (RENARD et al. 1997). However, in practice, especially when the assessment is done for large areas, some modifications of the original approach or simplified methods for factor approximation values are used. In many countries special research was done to determine the (R)USLE factor values using original methodology or to develop simplified, tuned to local condition, methods for their evaluation. Figure 5 presents the modeling workflow adopted for the erosion risk assessment in our study.

\subsubsection{Rainfall Erosivity Factor (R)}

Rainfall erosivity for a single rainfall occurrence is calculated as a sum of the rain kinetic energy and its maximum 30 min intensity. The annual sum of these figures forms the R-factor. For modeling purposes its value equals the mean value in recent years.

It is necessary to gather detailed meteorological (pluviographic) data to assess the value of the R-factor. Unfortunately, in Poland only ten measurement stations have gathered such data in recent years. Among them, only one is situated in Limanowa, in the Małopolska region (LicZnAR 2004). A very similar situation occurs in various parts of the world and it became the main reason to look for alternative methods of estimating R-factor values. Such methods should be based on data gathered regularly in measurement stations or on correlation with other

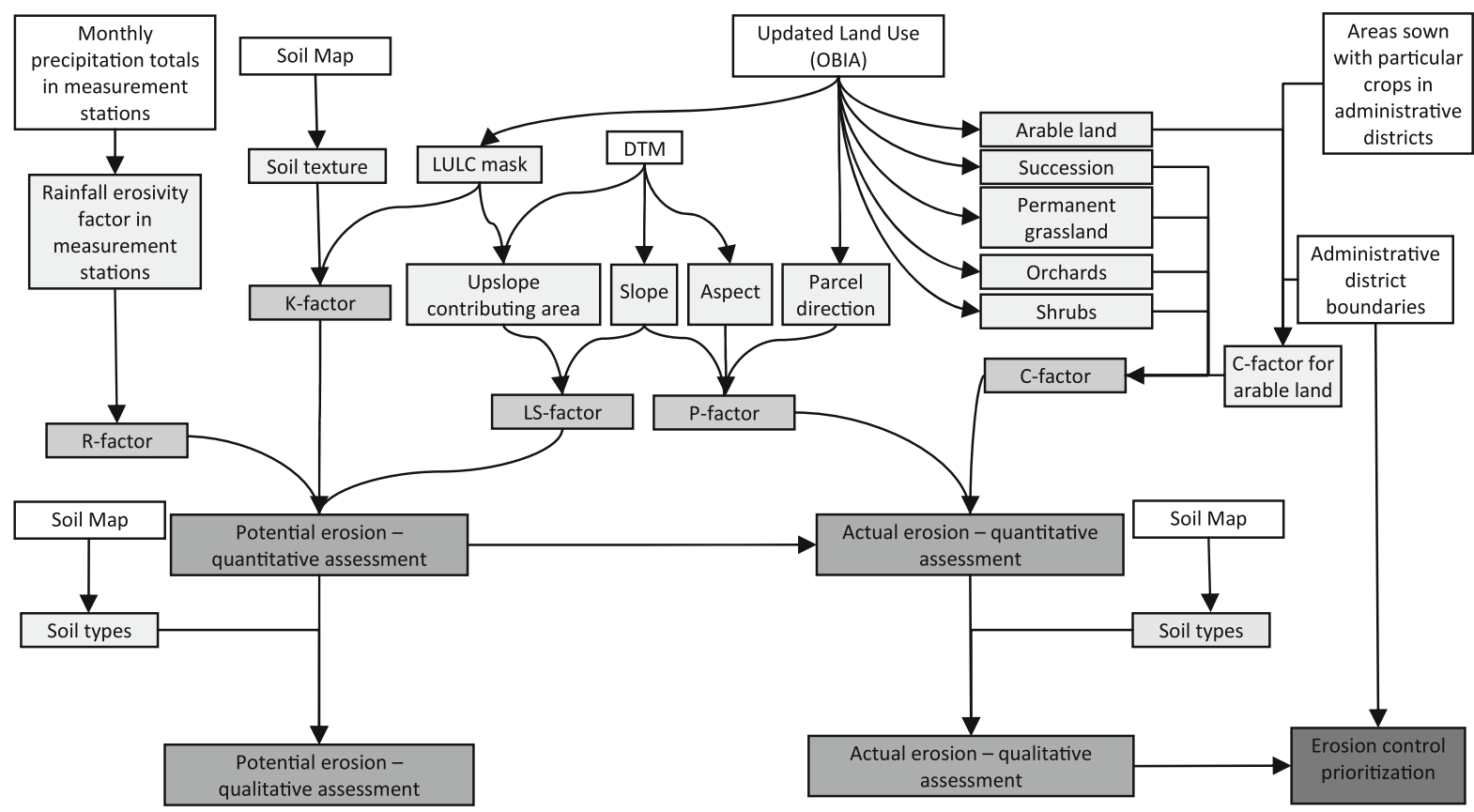

Figure 5

Assessment of erosion risk-data processing workflow 
easily accessible data. The former option was suggested for Poland by LicZnAR (2006). It was pointed out that there exists a correlation between the $\mathrm{R}$-factor value and the elevation at which the measurement stations are situated. However, this correlation was estimated on the basis of monthly precipitation totals in measurement stations from the years 1961-1980.

Among methods of estimating the rainfall erosivity factor, based on the precipitation data, the most often applied are the approaches that use the modified Fournier index (ARNOLDUs 1977):

$$
F=\sum_{i=1}^{12} \frac{p_{i}^{2}}{P}
$$

where $p_{i}$ is the monthly precipitation total in $i$-th month, $P$ is the annual precipitation total.

Many authors (RENARD and Freimud 1994; Coutinho and Tomas 1995) confirm the high correlation between values obtained with the Fournier index and R-factor values in the USLE equation.

Research on the applicability of monthly rainfall to estimate the R-factor was held in Poland by LICZNAR (2004). He claims that the best results to estimate the annual erosivity rainfall factor in Poland are obtained by using a modified Fournier index with an exponent correlation as in the following equation (LiCZNAR 2004):

$$
R=0.226 F^{1.2876}
$$

Equation (4) was used in the present survey to estimate the R-factor for the precipitation conditions of the Małopolska region. The R-factor values obtained in the measured locations were used for the interpolation of its spatial distribution. The regular co-kriging method was applied and the elevation above sea level was used as a support variable. The application of the co-kriging method was suggested according to other research done (GoovaerTs 1999; LiczNAR 2006); and also because of the high value of the correlation coefficient between the $\mathrm{R}$-factor values estimated in the measured locations and their elevation above sea level $\left(R^{2}=0.76\right)$. ArcGIS10 Geostatistical Analyst provided the tool for interpolation. Cross-validation was applied to select the model of the theoretical variogram, its parameters, and the size of the data search area. In this way the standard deviation of differences between the real and estimated values were kept to a minimum.

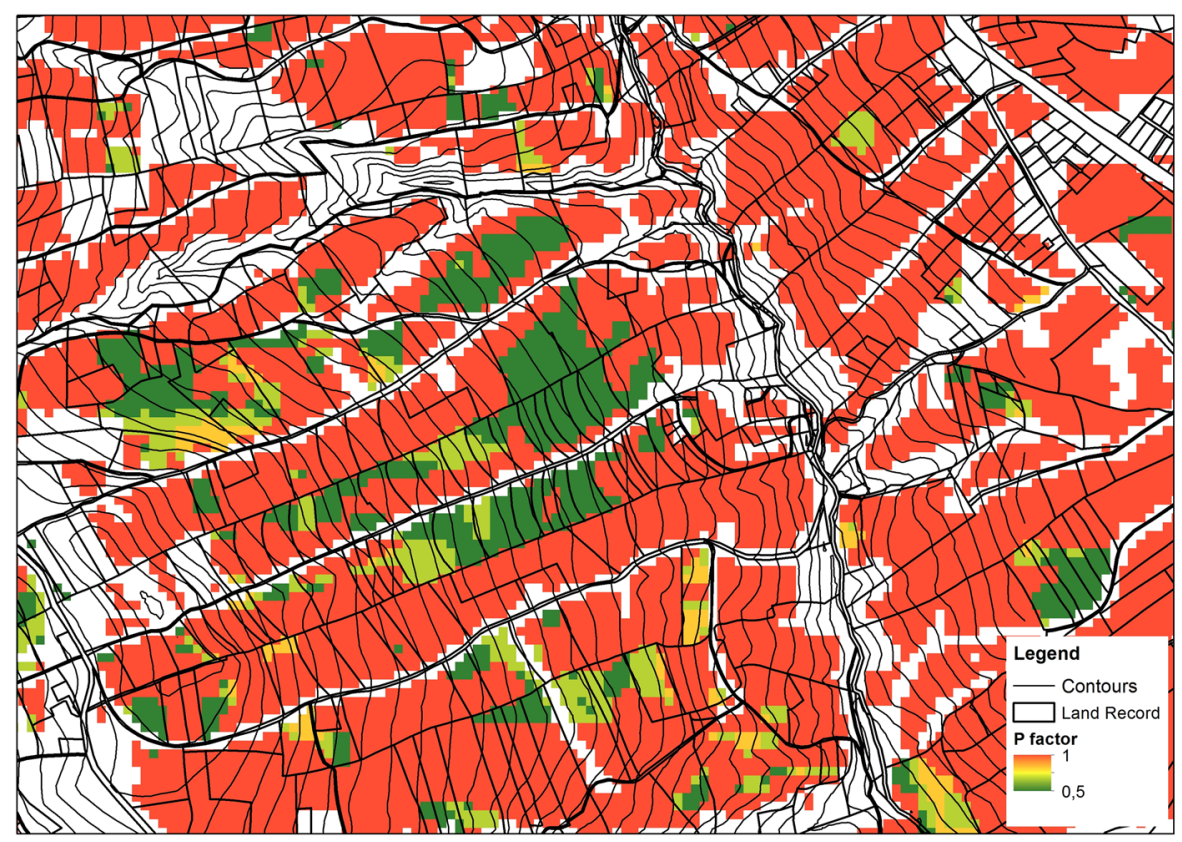

Figure 6

Enlargement of a P-factor value map 


\subsubsection{Soil Erodibility Factor (K)}

Measures taken on the testing fields provide data to estimate the value of the soil erodibility factor $(\mathrm{K})$. The original USLE model (WISCHMEIER and SMITH 1978) used a nomogram and an empirical formula developed based on these measures. RENARD et al. (1997) suggested two empirical equations to estimate the K-factor values for the (R)USLE model.

To satisfy the needs of the present survey, $\mathrm{K}$-factor values were assigned to particular soil types on the soil map. The K-factor values used were estimated for the various soil types of Poland and come mainly from the research done by the Institute of Soil Science and Plant Cultivation in Puławy, Poland (WAwer et al. 2005; STUCZYŃsKi et al. 2010).

The values presented in the mentioned sources do not include some Polish soil map types like rendzinas (heavy, medium, light) and clay loess. In the case of clay loess, its texture was defined as silt loam, according to Kolasa's research (KolASA 1961). In the case of rendzinas, its texture was defined after the analyses of source literature presenting the features of these soils in the area covered by the modeling (KoMORNICKI 1958; DOBRZAŃSKI et al. 1962; URBAŃSKI 2008). The texture of rendzinas was assumed as follows: light rendzina as a strong loamy sand (\%sand ca. $70, \%$ silt ca. 25 , \%clay ca.5), average rendzina as a light (sandy) loam (\%sand ca. 60, \%silt ca. 30, \%clay ca.10) and heavy rendzina as an average (sandy clay) loam (\%sand ca. 65, \% silt ca. 10, \%clay ca.25). Due to the fact that rendzina soils frequently contain many rock fragments, the K-factor values were raised by $25 \%$ (RENARD et al. 1997). Table 1 presents the K-factor values applied in the modeling.

\subsubsection{Topographic Factor (LS)}

The influence of the surface topography on erosion process is in the (R)USLE modeling approach,

Table 1

Values of the soil erodibility factor $(K)$

\begin{tabular}{|c|c|c|}
\hline Soil texture class & $\begin{array}{l}\text { K-factor value } \\
{[(\mathrm{t} * \text { acre*h }) /(\text { hundreds of acre*ft-tonf*in })]}\end{array}$ & $\mathrm{K}$-factor value $[(\mathrm{t} * \mathrm{ha} * \mathrm{~h}) /(\mathrm{ha} * \mathrm{MJ} * \mathrm{~cm})]$ \\
\hline Sandy gravel & $0.05 *$ & 0.06585 \\
\hline Loamy gravel & $0.12 *$ & 0.15804 \\
\hline Loose sand & 0.01 & 0.01317 \\
\hline Loose silty sand & $0.03 *$ & 0.03951 \\
\hline Weak loamy sand & 0.05 & 0.06585 \\
\hline Weak loamy silty sand & $0.14 *$ & 0.18438 \\
\hline Light loamy sand & 0.09 & 0.11853 \\
\hline Light loamy silty sand & $0.14 *$ & 0.18438 \\
\hline Strong loamy sand & 0.11 & 0.14487 \\
\hline Strong loamy silty sand & 0.34 & 0.44778 \\
\hline Light loam & 0.12 & 0.15804 \\
\hline Light silty loam & $0.16^{*}$ & 0.21072 \\
\hline Average loam & 0.09 & 0.11853 \\
\hline Average silty loam & $0.19 *$ & 0.25023 \\
\hline Heavy loam & 0.06 & 0.07902 \\
\hline Heavy silty loam & $0.12 *$ & 0.15804 \\
\hline Silt & 0.31 & 0.40827 \\
\hline Silt loam & $0.32 *$ & 0.42144 \\
\hline Clay & $0.05^{*}$ & 0.06585 \\
\hline Silty clay & $0.22 *$ & 0.28974 \\
\hline Loess & 0.28 & 0.36876 \\
\hline Clay loess & $0.32^{\#}$ & 0.42144 \\
\hline Light rendzina & $0.13^{\#}$ & 0.17121 \\
\hline Average rendzina & $0.15^{\#}$ & 0.19755 \\
\hline Heavy rendzina & $0.11^{\#}$ & 0.14487 \\
\hline
\end{tabular}

(Source: WAWER et al. 2005; * STUCZYŃSKI et al. 2010; ${ }^{*}$ own estimation) 
incorporated by the use of the topographic factor (LS). It combines two features-slope length (L) and slope steepness (S). The aim of the USLE equation was to estimate the soil loss in the erosion process for uniform slopes having the same steepness over their entire length. The slope length is defined as the horizontal distance (not the distance parallel to the soil surface) from the origin of the overland flow to the point where either the slope gradient decreases enough that deposition begins, or runoff becomes concentrated in a defined channel (WISCHMEIER and Smith 1978; Renard et al. 1997). When the slope length is measured in meters, the L-factor value is calculated as follows (WISCHMEIER and SMITH 1978):

$$
L=\left(\frac{\lambda}{22.13}\right)^{m}
$$

where $\lambda$ is the slope length, $m$ is the slope length exponent ( $m=0.5$ for steepness of $5 \%$ or more; $m=0.4$ for steepness of $3.5-5 \% ; m=0.3$ for steepness of $1-3.5 \% ; m=0.2$ for steepness $<1 \%$ ).

The slope steepness factor (S) can be calculated as follows (WISCHMEIER and SMITH 1978):

$$
S=65.41 \sin ^{2}(q)+4.56 \sin (q)+0.65
$$

where $q$ is the slope steepness.

In the case of slopes having an irregular steepness (convex, concave or complex), the LS-factor is estimated by a technique in which the slope is divided into segments of uniform steepness. The LS-factor is calculated as follows (FosTER and WischMEIER 1974; WischMeIER and SMITH 1978; RENARD et al. 1997):

$$
\mathrm{LS}=\sum_{j=1}^{N} \frac{S_{j} \lambda_{j}^{m+1}-S_{j} \lambda_{j-1}^{m+1}}{\left(\lambda_{j}-\lambda_{j-1}\right)(22.13)^{m}}
$$

where $S_{j}$ is the slope steepness factor for the slope $j$-th segment, $\lambda_{j}$ is the length from the top of the slope to the lower end of the $j$-th segment, $M$ is the exponent of the slope length factor.

The aim of slope segmentation, according to its steepness values, was to model the impact of terrain curvature on erosion in the direction of the maximum steepness (i.e. overland water flow). Many authors (MoOre and Burch 1986, 1992; Desmet and Govers 1996; Mitasova et al. 1996) have proved that the influence of terrain form on the overland water flow is accounted better when the slope length factor (L) is replaced by a unit upslope contributing area. If the slope segments are represented as raster cells, the unit upslope contributing area for each raster cell equals the division of the cell upslope contributing area by the distance that the flowing water covers within the raster cell.

DESMET and Govers (1996) suggest a modified method of estimating the L-factor for a single raster cell in GIS systems. They take into account the possibility of replacing the slope length value by a unit upslope contributing area:

$$
L_{(i, j)}=\frac{\left(A_{(i, j)}+D^{2}\right)^{m+1}-A_{(i, j)}^{m+1}}{x^{m} D^{m+2}(22.13)^{m}}
$$

where $D$ is the resolution of the DTM raster cell, $A_{(i, j)}$ is the unit upslope contributing area at the entrance to $(i, j)$ raster cell, $X$ is the coefficient correcting the flow length within the raster cell, depending on the direction of flow and estimated on the basis of the terrain aspect.

In the present survey, the LS-factor was calculated with the use of Eqs. (5)-(8). Some land cover classes (forest, water, developed areas, infrastructure) were excluded from estimating the upslope contributing area. This fact influences the LS-factor values. Such an approach was based on the fact that a substantial overland flow begins at the edge of a forested area. In the case of water, developed areas, and infrastructure, overland flow transformation and concentration occurs (RENARD et al. 1997; WINCHELL et al. 2008).

\subsubsection{Cover Management Factor (C)}

The cover management factor (C) reflects the effect of cropping and management practices on erosion rates. It is calculated as the ratio of soil loss under actual conditions to losses experienced under the reference conditions (continuously fallow and tilled land) (RENARD et al. 1997). Determination of the $\mathrm{C}$-factor value for agricultural crops requires detailed research of anti-erosion protection offered by a vegetation canopy at different growth stages and a reduction in erosion caused by surface cover and roughness. Previous cropping and management 
practices should be taken into account as well as the monthly changes of the rainfall erosivity factor.

In some countries, $\mathrm{C}$-factor values resulting from such research for the most often crop rotation practices are tabulated. For conditions in Poland, this kind of table describing the fully possible crop rotations has not yet been elaborated. In previous erosion research, the crop and management factor values were adopted from tables created in the USA or Bavaria (LicZnAR 2003). Based on Bavarian research, C-factor values for the most typical Polish crops were proposed by Koneleski (1992). The newest proposal of $\mathrm{C}$-factor values for basic Polish crops can be found in the work by STUCZYŃSKI et al. (2010).

In the presented study, maps showing the spatial distribution of the crop and management factor for the Małopolska region were created as follows:

- a C-factor value of 0.01 was assigned to agricultural parcels classified as orchards, permanent grassland, afforestation, and shrubs as well as to the grounds identified as secondary forest succession areas;

- for the remaining agricultural grounds (arable lands), the C-factor value was evaluated for each municipality separately based on statistical data about the areas sown with particular crops using values proposed by STUCZYŃSKI et al. (2010) (Table 2):

A uniform C-factor value was assigned to all arable lands in each particular municipality, calculated as a weighted average based on shares of particular crops in the entire area of arable lands sawn in the administrative unit. Information about the areas sown with particular crops was basically taken from the data provided by the Polish Central Statistical Office based on the National Agricultural Census from 2002. The analogical data from the agricultural census taken in 2010 has not been available on such a detailed level yet. However, the 2010 data was available at a coarser level of the entire region and the groups of crops. This data was disaggregated based on the following assumptions:

1. Changes took place uniformly in the entire voivodeship, which means that the ratio of particular crop (or crop group) acreage in a given municipality to its acreage in the voivodeship is the same for 2010 and 2002.

2. The shares of particular crops in crop groups do not change at the municipal level. This assumption was necessary as some crops mentioned for 2002 were aggregated into crop groups in the 2010 statistical data. Based on this assumption, when the acreage of the crop group was evaluated for the given municipality in 2010 , the shares of the particular crops were calculated similarly to 2002 .

3. The total acreage of crops calculated for all municipalities must equal the acreage of crops stated for the entire voivodeship.

4. The shares of the particular crops in every municipality must sum up to $100 \%$.

\subsubsection{Erosion Control Practice Factor $(P)$}

Erosion control practice factor $(\mathrm{P})$ describes the ratio between soil loss on a field where erosion control practice is performed (contouring, strip cropping, terracing, subsurface drainage) to the loss on the

Table 2

Crop types and their $C$-factor values

\begin{tabular}{ll}
\hline Crop type & $C$ \\
\hline Black fallow & 1.00 \\
Green fallow & 0.01 \\
Winter wheat & 0.15 \\
Spring wheat & 0.18 \\
Rye & 0.15 \\
Winter barley & 0.15 \\
Spring barley & 0.18 \\
Oats & 0.18 \\
Winter wheat-rye & 0.15 \\
Spring wheat-rye & 0.18 \\
Winter mixed cereal & 0.15 \\
Spring mixed cereal & 0.18 \\
Maize & 0.22 \\
Buckwheat, millet and other cereals & 0.18 \\
Potatoes & 0.22 \\
Sugar beet & 0.22 \\
Winter rape & 0.15 \\
Spring rape & 0.18 \\
Fodder bulb plants & 0.22 \\
Soil-grown vegetables & 0.22 \\
Other fodder crop & 0.18 \\
Other industrial crop & 0.18 \\
Other & 0.22 \\
\hline
\end{tabular}


same field with upslope and downslope tillage (RENARD et al. 1997). In the present survey, due to the large area that it covers and the source data used, the P-factor is only applied to plots with contouring.

Values of the P-factor for parcels cultivated with contour tillage were defined according to the USLE methodology (WISCHMEIER and SMITH 1978) as follows:

$$
\begin{aligned}
& P=1 \text { for slope steepness }<3 \%, \\
& P=0.5 \text { for slope steepness } 3-8 \%, \\
& P=0.6 \text { for slope steepness } 8-12 \%, \\
& P=0.7 \text { for slope steepness } 12-16 \%, \\
& P=0.8 \text { for slope steepness } 16-20 \%, \\
& P=0.9 \text { for slope steepness } 20-25 \%, \\
& P=1 \text { for slope steepness }>25 \% .
\end{aligned}
$$
1.

On other land the P-factor value was assigned to

Photo interpretation of aerial or satellite orthophotomaps with overlaid contour lines can be used to identify fields with contour tillage (DRZEWIECKI 2008). Due to the size of the surveyed area, this process had to be automated.

For deriving $P$-values, the OBIA method was applied. The eCognition software allows one to import vector data together with raster layers; that ability was used to create the analysis workspace. Having taken into account the oblong field shape typical for Małopolska, it was assumed that the majority of the plots are cultivated along their longer edge. This direction was derived in the eCognition software from the land parcels layer (updated during the classification process) by the Mean Direction function. A new raster dataset was created based on this value and assigned to each vector object. The value was then compared to the aspect direction. Cells where these two directions were perpendicular ( \pm 15 degrees), were treated as cultivated with contour tillage and assigned the appropriate $P$-values.

\begin{tabular}{|c|c|c|c|}
\hline Erosion class & Erosion class description & Erosion rate $\left[\mathrm{t} \mathrm{ha}^{-1}\right.$ year $\left.^{-1}\right]$ & $\begin{array}{l}\text { Erosion rate }\left[\mathrm{t} \mathrm{ha}^{-1} \text { year }^{-1}\right] \\
\text { for rendzina soil }\end{array}$ \\
\hline 1 & No erosion & $0-2$ & $0-2$ \\
\hline 2 & Low erosion & $2-10$ & $2-6$ \\
\hline 3 & Moderate erosion & $10-30$ & $6-15$ \\
\hline 4 & Average erosion & $30-50$ & $15-30$ \\
\hline 5 & Strong erosion & $50-100$ & $30-65$ \\
\hline 6 & Very strong erosion & $>100$ & $>65$ \\
\hline
\end{tabular}
(Fig. 6).

Table 3

Erosion classes and soil degradation (Source: JÓZEFACIUK and JÓZEFACIUK 1996; WAWER and NOWOCIEŃ 2007)

\begin{tabular}{lll}
\hline $\begin{array}{l}\text { Erosion } \\
\text { class }\end{array}$ & $\begin{array}{l}\text { Erosion class } \\
\text { description }\end{array}$ & Soil degradation \\
\hline 1 & $\begin{array}{l}\text { No erosion } \\
\text { Weak erosion } \\
\text { Moderate erosion }\end{array}$ & $\begin{array}{l}\text { Does not occur } \\
\text { Small surface soil loss } \\
\text { Visible wash-off of humus horizon and deterioration of soil properties; full regeneration of soil not always } \\
\text { possible through conventional tillage }\end{array}$ \\
4 & Average erosion & $\begin{array}{c}\text { May lead to a total reduction of humus horizon and the development of soils with typologically unformed } \\
\text { profiles; terrain dismemberment starts; considerable debris flow into surface waters } \\
\text { Can cause total destruction of the soil profile, including parent rock; large fragmentation of terrain and } \\
\text { deformation of hydrology } \\
\text { Effects similar to the ones for strong erosion, but more intensive; a permanent degradation of the ecosystem }\end{array}$ \\
6 & $\begin{array}{c}\text { Strong erosion } \\
\text { Very strong } \\
\text { erosion }\end{array}$ & \begin{tabular}{c} 
\\
\hline
\end{tabular}
\end{tabular}

Table 4

Classification of potential erosion 
Table 5

Classification of actual erosion

\begin{tabular}{|c|c|c|c|}
\hline Erosion class & Erosion class description & Erosion rate $\left[\mathrm{t} \mathrm{ha}^{-1}\right.$ year $\left.^{-1}\right]$ & $\begin{array}{l}\text { Erosion rate }\left[\mathrm{t} \mathrm{ha}^{-1} \text { year }^{-1}\right] \\
\text { for rendzina soil }\end{array}$ \\
\hline 1 & No erosion & $0-1$ & $0-1$ \\
\hline 2 & Low erosion & $1-5$ & $1-3$ \\
\hline 3 & Moderate erosion & $5-10$ & $3-5$ \\
\hline 4 & Average erosion & $10-15$ & $5-10$ \\
\hline 5 & Strong erosion & $15-30$ & $10-20$ \\
\hline 6 & Very strong erosion & $>30$ & $>20$ \\
\hline
\end{tabular}

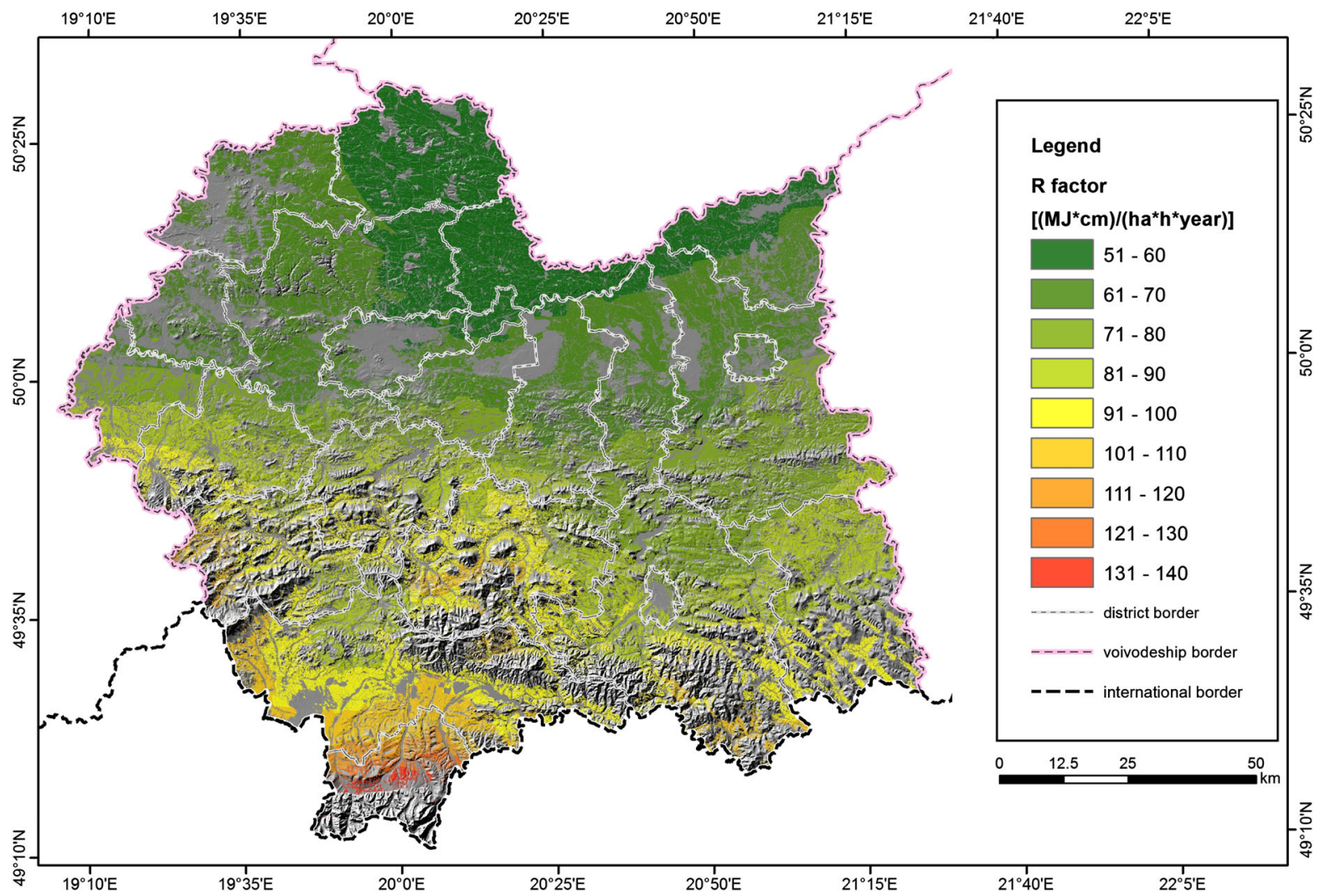

Figure 7

Spatial distribution of R-factor values

\subsubsection{Potential and Actual Erosion Risk}

The potential and actual erosion rates were assessed for each raster cell according to Eqs. (2) and (1), respectively. Based on the quantitative evaluation of soil erosion resulting from USLE modeling, the qualitative assessment of erosion risk for the area of Małopolska was done in the survey. According to the forecast soil loss, each raster cell was assigned to one of the six erosion risk classes, with an assumption that the soil degradation level in each particular erosion class should correspond to grades of erosion intensity introduced by JózeFACIUK and JózeFACIUK (1996) in Poland (Table 3).

Border values of soil loss for each class (Tables 4, 5) were defined according to literature (SCHMIDT 1989; KoRELESKI 2005; STUCZYŃSKI et al. 2010). Rendzina soils were given different criteria than 


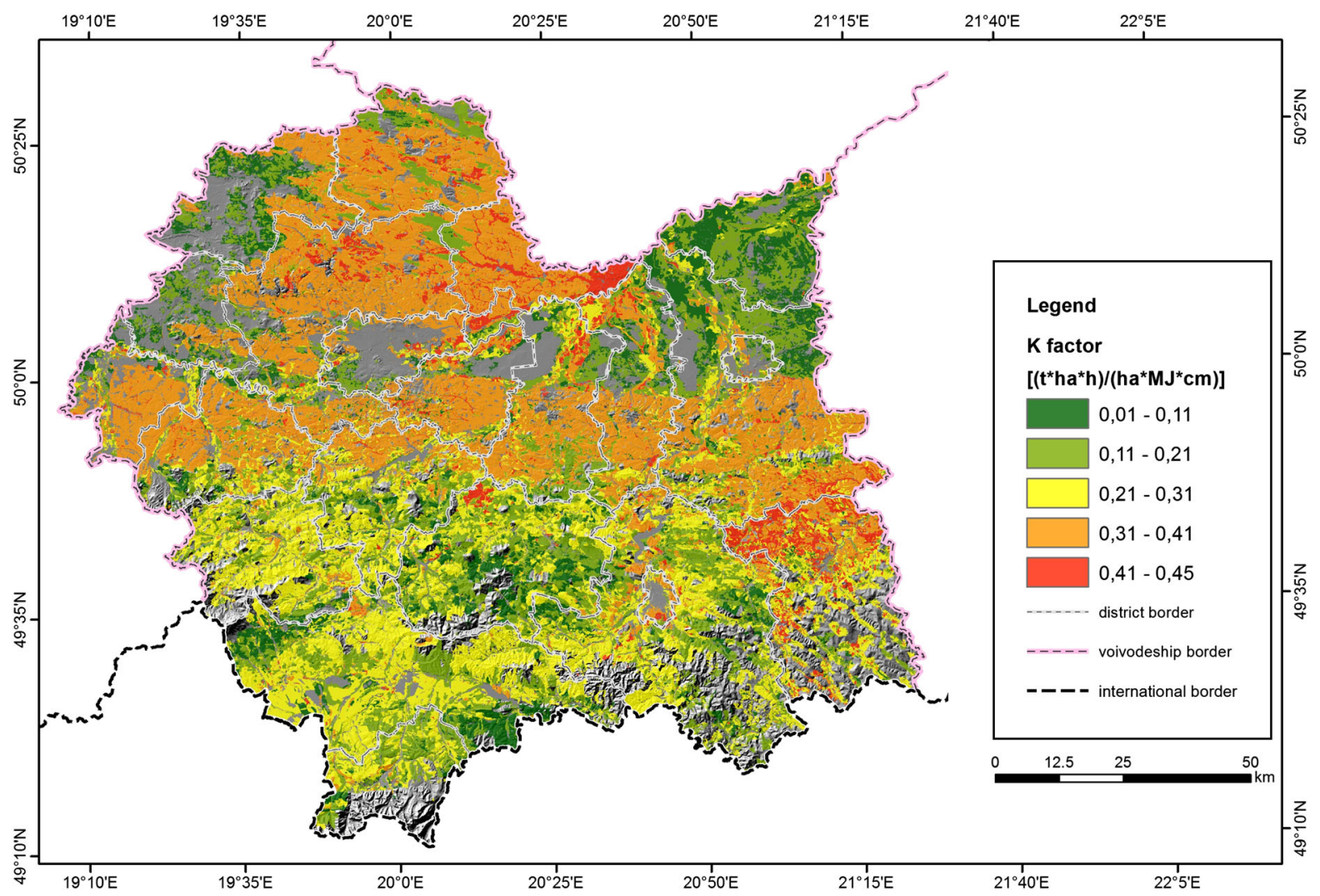

Figure 8

Spatial distribution of the K-factor values

other soils. It was justified by the profile, which in the case of rendzina is rather limited with rocky and stony fragments situated near the surface. The same level of erosion intensity results in bigger soil degradation.

\subsection{Urgency of Erosion Control Practice}

The present survey results provided the basis for an analysis of erosion risk in the voivodeship and in smaller administrative units (district, municipality). In Poland, three levels of urgency of anti-erosion prevention are in use (JózEFACIUK and JózEFACIUK 1975):

- very urgent erosion control-occurs when over $25 \%$ of the arable land of the administrative unit faces an average or higher erosion risk,

- urgent erosion control-occurs when 10-25\% of the arable land of the administrative unit faces an average or higher erosion risk,
- less urgent erosion control-occurs when up to $10 \%$ of the arable land of the administrative unit faces an average or higher erosion risk.

\section{Results}

\subsection{LULC Change}

The content of the original soil map LULC database was compared with the updated one and presented in a table. It allows a synthetic assessment of landscape changes in the Małopolska region over the last 50 years.

The results obtained support the claim that the most significant changes took place in forested areas (an increase of $+8.2 \%$, i.e. $125,000 \mathrm{ha}$ ) and developed areas (an increase of $+6.7 \%$, i.e. over 100,000 ha). A substantial decrease was observed in the class of arable land $(-10.4 \%$, i.e. 166,000 ha) 


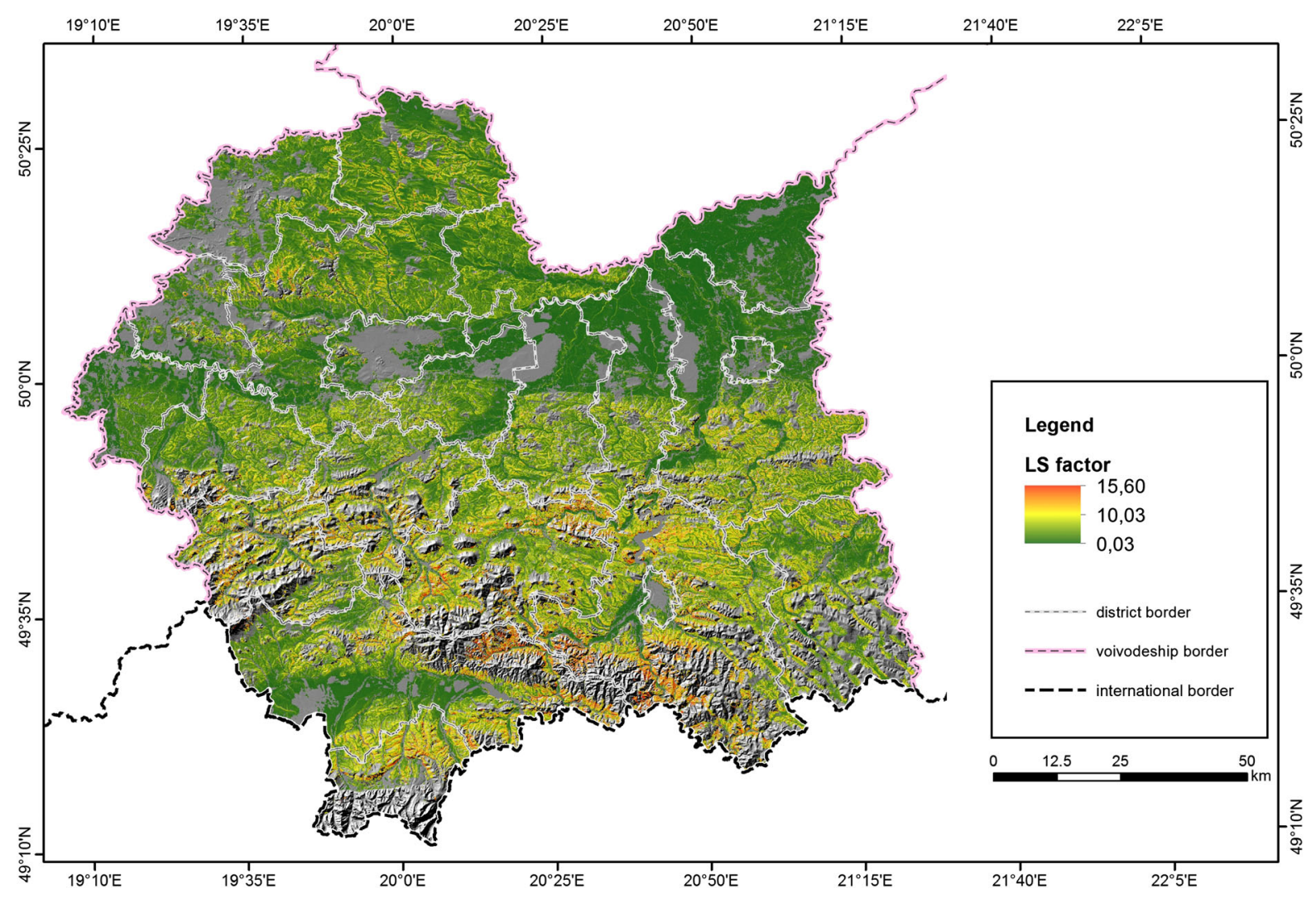

Figure 9

Spatial distribution of LS factor values

and permanent grasslands ( $-4.2 \%$, i.e. 63,000 ha). Marginal changes took place in the class of soils unsuitable for agriculture $(-4 \%$, i.e. 500 ha), wasteland $(-8,000 \mathrm{ha})$ and water $(+0.3 \%$, i.e. $5,000 \mathrm{ha})$.

\subsection{Erosion Risk Modeling}

Figures 6, 7 presents the spatial distribution of the R-factor in the Małopolska Voivodeship. The analysis of the map shows essential spatial differentiation. R-factor obtians higher values in the southern mountainous part of the region. The R-factor values in this area reach over $100(\mathrm{MJ} * \mathrm{~cm}) /\left(\mathrm{ha}^{*} \mathrm{~h} * \mathrm{y}\right)$. These results are similar to other research (LiczNAR 2006). The northern parts of Małopolska have much lower $\mathrm{R}$-factor rates. The minimum value is three times lower than the maximum value.

Figure 8 shows the spatial distribution of $\mathrm{K}$-factor values in the Małopolska Voivodeship.
Soil classes with high erodibility are situated in the central and northern parts of the area. They are mostly silty soils with loess prevailing. Lower erodibility is typical for soil classes in most of the mountainous parts of the voivodeship. The northeast outskirts of the region have the lowest erodibility factor.

Figure 9 presents the spatial distribution of the LS-factor in the Małopolska Voivodeship. Due to the variety of land forms in the region, the LS-factor reaches high values, especially in the mountains in the south. However, even in mountainous areas there are areas of low LS-factor values among which the Podhalańska Plane is the biggest. Also, the complicated topography of the karst land forms in the north of Małopolska causes a high water erosion risk. A large area with low LS-factor values covers the central part of the voivodeship with the Vistula valley. 


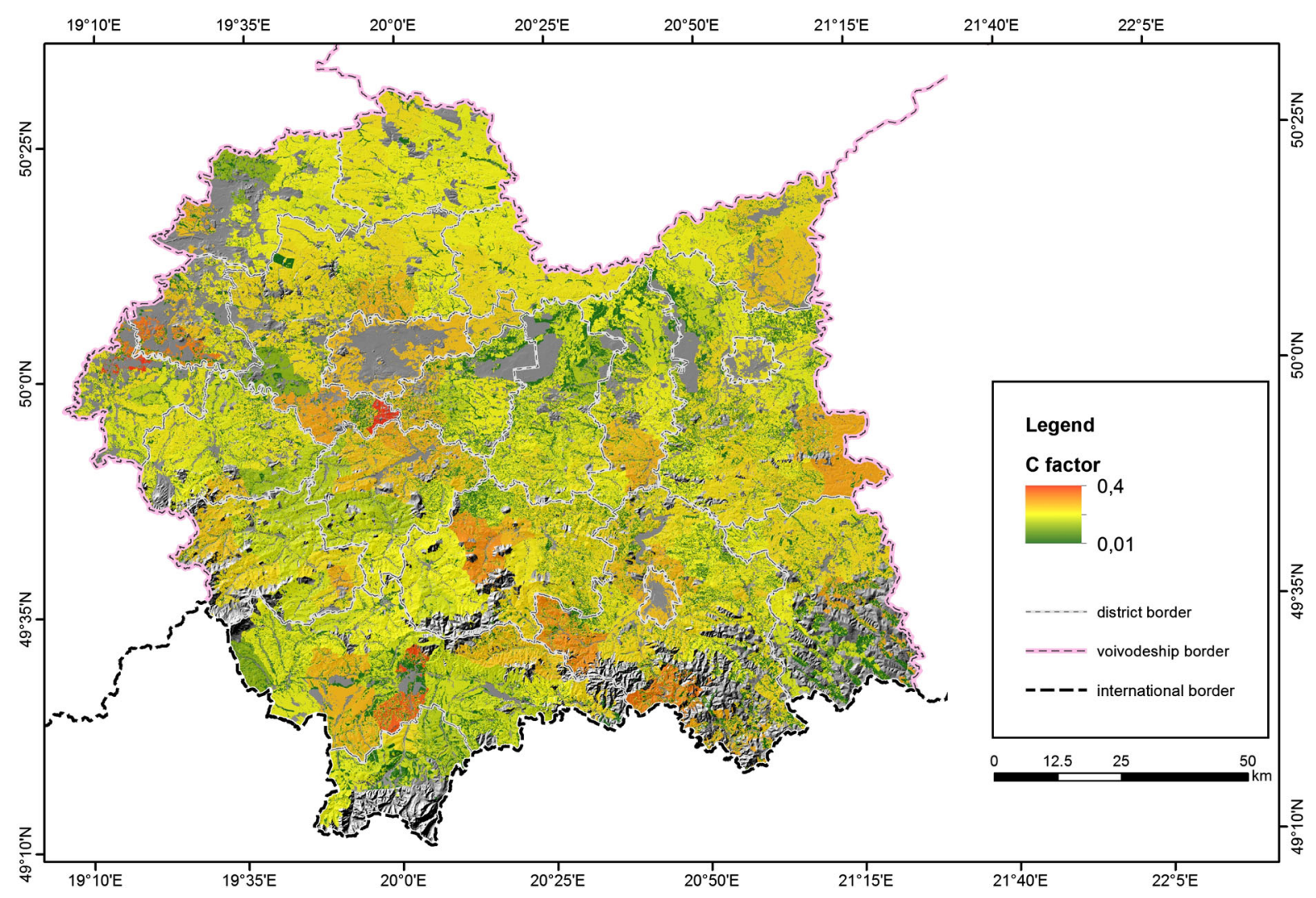

Figure 10

Spatial distribution of $\mathrm{C}$ factor values

Spatial distribution of C-factor values calculated for the Małopolska region is shown in Fig. 10. For arable lands these values were in the range from 0.11 (Czernichów municipality) to 0.40 (Świątniki Górne municipality).

Figure 11 presents the spatial distribution of P-factor values. These values show some level of spatial variation within the voivodeship. The average value calculated for particular municipalities is in a range from 0.94 to 1.00. The average for Małopolska equals 0.97 .

Figures 12 and 13 present the results of the quantitative assessment of potential and actual erosion intensity. The mean value of the annual potential erosion rate calculated for agricultural lands in Małopolska equals $23.0 \mathrm{t} / \mathrm{ha}$. The highest mean values were obtained for municipalities located in the south mountainous part of the region with a maximum average annual rate of $76.7 \mathrm{t} / \mathrm{ha}$ for Rytro. The lowest rates of potential erosion characterize the north-eastern part of Małopolska, with the minimum average annual rate as low as $0.8 \mathrm{t} / \mathrm{ha}$ for the Olesno municipality.

A qualitative assessment of the potential erosion risk for soils in the Małopolska region (Figs. 14, 15; Tables 6, 7) reveals that only slightly more than $15 \%$ of the arable land is free from the hazard of erosion. As much as $28.63 \%$ of this area faces average or strong potential erosion, which may result in a long-term degradation of the soil profile.

Assessment of actual erosion risk reveals that, in fact, the real erosion risk is much lower than the potential one. Over $40 \%$ of the arable land is not experiencing any erosion processes. Average or strong erosion applies only to $10 \%$ of the area. Similarly to potential erosion, the highest mean values of annual erosion rates were obtained for some mountainous municipalities. The exception is the municipality of Świątniki Górne, where a 


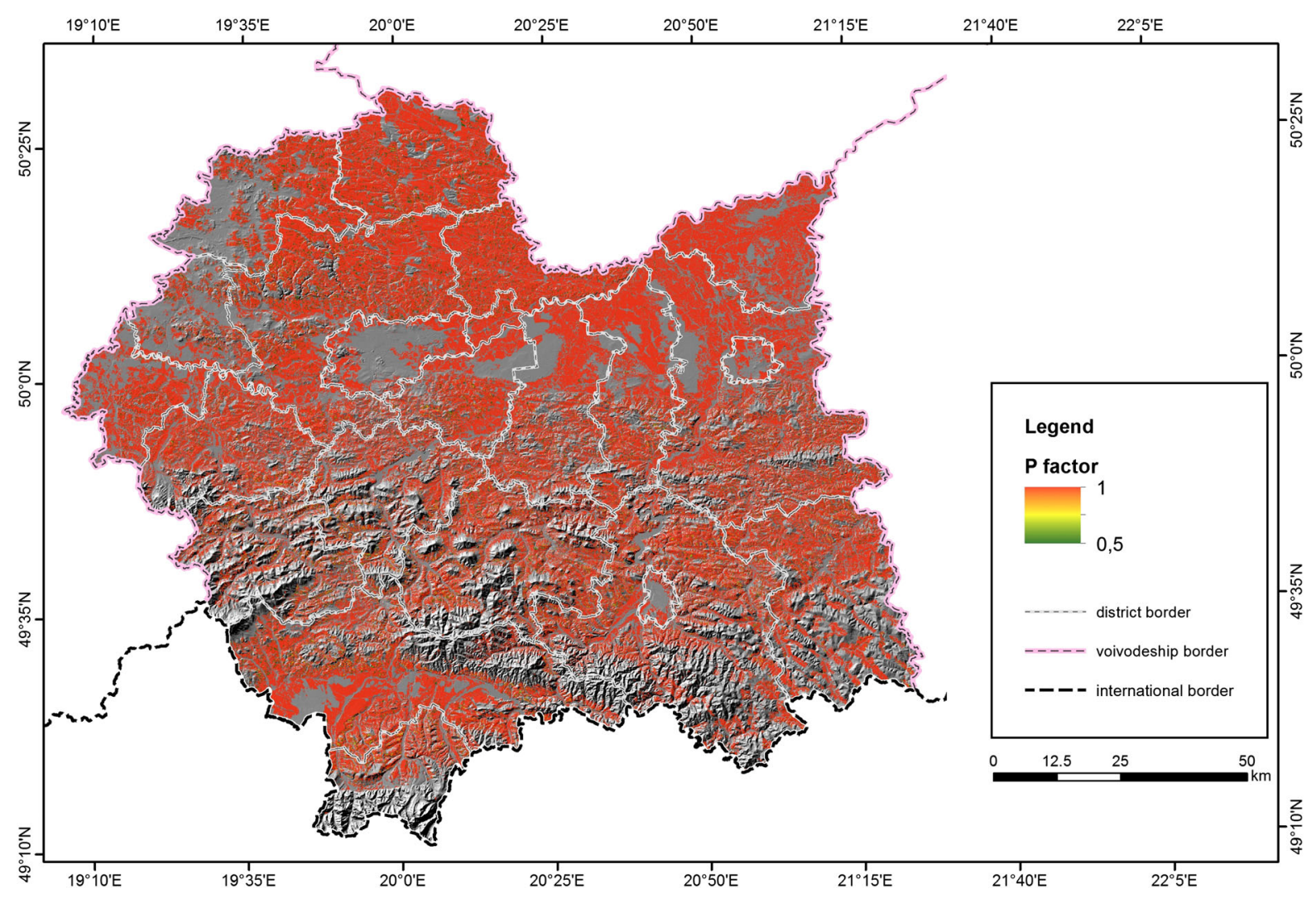

Figure 11

Spatial distribution of $\mathrm{P}$ factor values

maximum rate of $13.8 \mathrm{t} / \mathrm{ha}$ was calculated. For the area located in the Wieliczka Foothills, and adjoining the City of Cracow, the highest $\mathrm{C}$-factor value was calculated as well. The mean value for Małopolska was assessed at $3.8 \mathrm{t} / \mathrm{ha}$. Again, the north-eastern part of the voivodeship is the region with the lowest erosion risk (with the minimum rate for Olesno equaling $0.1 \mathrm{t} / \mathrm{ha})$.

According to the adopted rules of anti-erosion prevention, in the Małopolska Voivodeship considered as an regional administrative unit; urgent erosion control is required. Over $10 \%$ of the total arable land faces a medium or strong actual erosion risk. However, the urgency level of anti-erosion protection in the administrative units varies significantly (Fig. 16).

In $20 \%$ of the municipalities there is a very urgent demand for erosion control. In the next $23 \%$ an urgent erosion control is needed. However, most of the municipalities (103 out of 182) do not need urgent anti-erosion prevention. The north of the region demands the least erosion control practice.

\subsection{Influence of P-Factor Estimation on Erosion Risk Modeling}

To assess the importance of an OBIA-based assessment of the P-factor on the erosion risk model, the results obtained in the study were compared to the results obtained when the P-factor value is equal to 1 . Such an approach, assuming no erosion control practices are used, is the most frequent one in regional scale studies (VRIELING 2006; TetzlafF et al. 2013; Terranova et al. 2009; Cebecauer and Hofierka 2008; Deumlich et al. 2006). The actual soil erosion map was re-calculated and the prioritization of administrative units repeated.

When looking into the comparison results for the entire voivodeship area, the influence of an adopted P-factor assessment methodology seems to be weak 


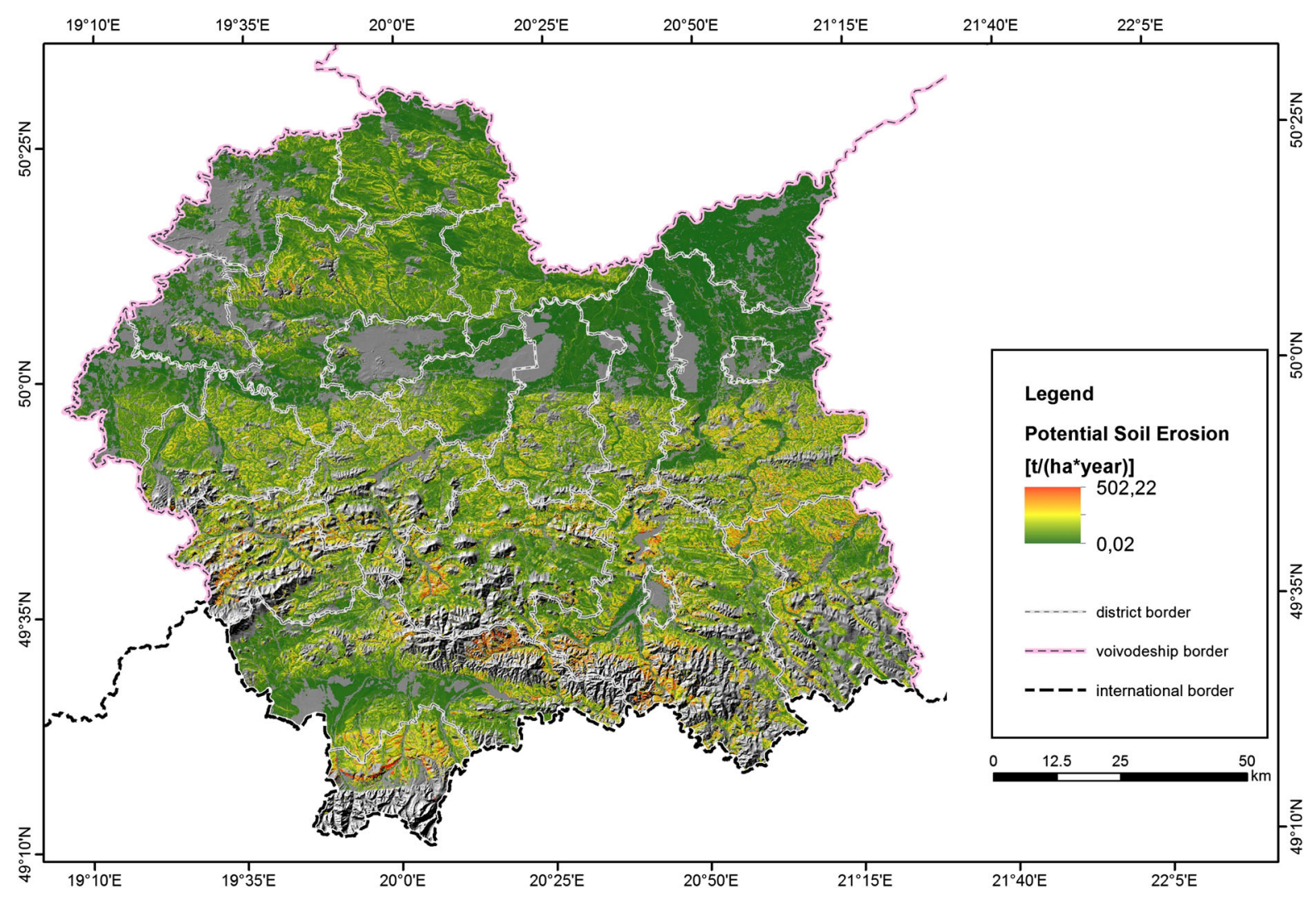

Figure 12

Quantitative assessment of potential soil erosion

(Table 8). The mean value calculated for the entire Małopolska Voivodeship is only $0.1 \mathrm{t} /$ ha higher than previously calculated. The size of the area calculated as the sum of the three highest erosion classes (i.e. the areas where erosion may cause irreversible damage in the soil profile) differs as little as 4,268 ha $(0.6 \%$ of the agricultural land area in the voivodeship). However, when the rules of erosion control urgency for administrative units are applied, this subtle change causes substantial differences in the assessment results (Fig. 17). Applying the OBIA based assessment of contour tillage caused a decrease of erosion control urgency levels for nine municipalities (from very urgent to urgent-three cases; from urgent to less urgent-six cases). Changes in the percentage of the agricultural lands seriously endangered by erosion (classes 4-6) for particular municipalities are in a range from 0.0 to 4.7. For 59 (from 182) municipalities these changes resulted in a change of the rank (from 1 to 5 positions) in the erosion control urgency level hierarchy.

\section{Discussion and Conclusions}

The quantitative and qualitative assessment of the erosion risk for the soils of the Małopolska region was done based on the USLE approach, with the use of GIS spatial modeling. However, it was essential to define, at first, the present land use and land cover. Such an elaborate task for an area of $15,000 \mathrm{~km}^{2}$ would not be completed without remotely-sensed data. Although there are accessible aerial photos that cover the whole area, it would be irrational to use this data for updating the land use map. It would result in a costly time and work consuming process. Using RapidEye satellite images in the project guaranteed an effective and economical task completion within the set time limits. The spatial resolution of the 


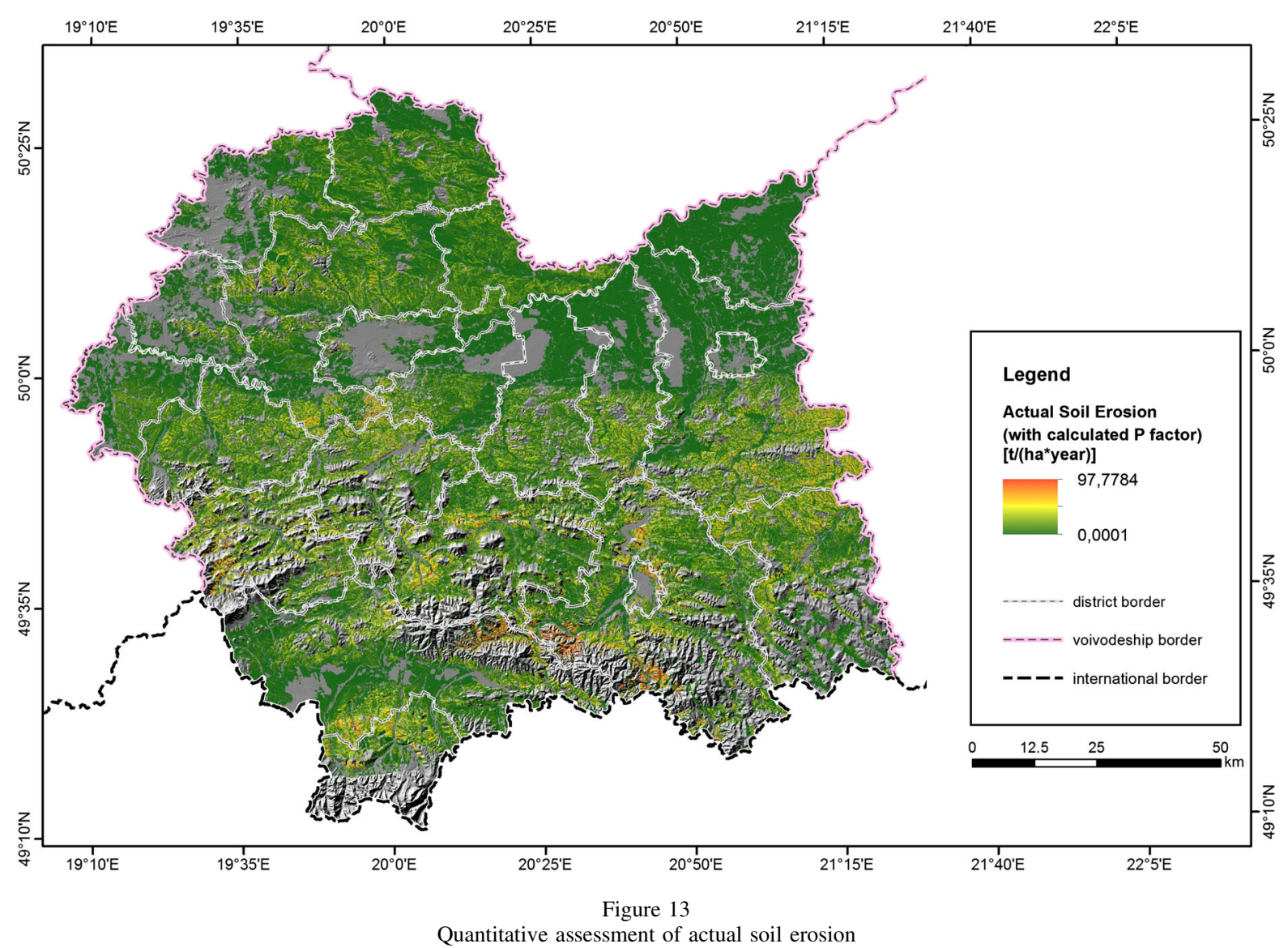

images also provided the necessary level of accuracy in the results.

Thanks to the application of the OBIA method, a high accuracy level of classification was obtained. This technology allowed the use of not only the original and processed (NDVI, principal components images) satellite data but also information from aerial orthophotomaps (Laplace filtration), the topographical database, and the land register maps. Establishing the object hierarchy was an important factor in reaching satisfactory classification results.

The LULC change analysis in the Małopolska region shows that forested and developed areas increased their sizes substantially, mainly as a result of the conversion from arable land or grassland. The real growth of developed areas is probably lower than those suggested by the results, as in the 1960s only densely inhabited areas were mapped. Sparse developments were almost completely omitted in the original soil map. Nevertheless, the described LULC changes correspond to trends observed in this time in Poland (KozAK 2003). Abandonment of agricultural land could result in forest development due to the natural succession or planned forestation.

The results of the erosion assessment in the Małopolska Voivodeship reveal the fact that a majority of its agricultural lands is characterized by moderate or low erosion risk levels. However, highresolution erosion risk maps show its substantial spatial diversity. According to our study, average or higher actual erosion intensity levels occur for $10.6 \%$ of agricultural land, i.e. $3.6 \%$ of the entire voivodeship area. This erosion risk level is much lower than $25 \%$ of the total region area reported by WAWER (2007), and much higher than $25 \%$ evaluated for agricultural lands based on the European-scale PESERA project results (KIRKBY et al. 2004). We believe that our results are more reliable. The WAWER (2007) results seem to be an overestimation, resulting from the adopted approach. In this study, the actual 


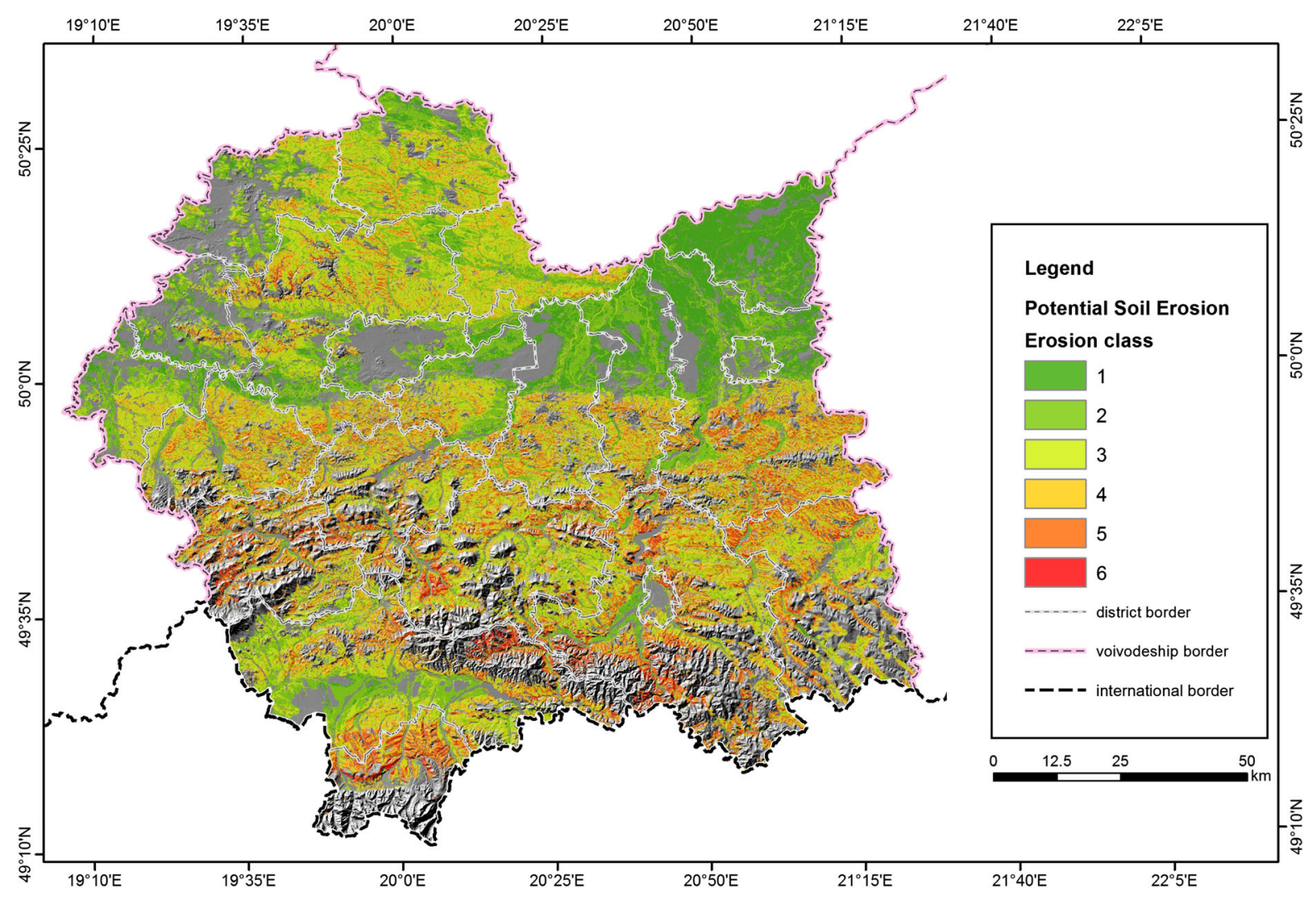

Figure 14

Potential soil erosion risk-qualitative assessment

erosion risk is based on the Corine CLC2000 land use classes. In this database, the minimal mapping unit was as large as 25 ha. In the case of Małopolska, this resulted in an overestimation of agriculture as average plot size is much smaller and the land use pattern is a mosaic of small arable lands and grasslands. On the other hand, the results of PESERA project are probably underestimated because of the spatial resolution of the datasets (especially DTM) used.

Due to unfavorable topographic conditions and very high values of the rainfall erosivity factor $(\mathrm{R})$, the most endangered soils are in the mountainous part in the south of the region. The least erosion risk applies to river valleys, i.e., Vistula and its main tributaries. The results of modeling done in the present study suggest that in the Małopolska region the precipitation and land forms have a stronger impact on erosion hazard than soil type; the northern part of the voivodeship provides a good example. Despite the erosion prone loess soils there, the area does not face a strong erosion risk. It is the result of relatively low values of rainfall (annual total 400-550 $\mathrm{mm}$ ) and low slope steepness. Low values of the USLE model factors of rainfall erosivity (R) and topography (LS) reflect and confirm these facts. In the north (similarly to other loess soils), a risk of local erosion after intense rainfall exists. This, however, requires a more detailed analysis of the single plots as well as a field survey.

A potential erosion risk is substantially higher than an actual one. This fact suggests that farming practices and cultivation methods used in Małopolska limit the development of erosion processes. However, this is not the case in every part of the region. The best example is in the municipality of Światniki Górne where the highest annual average of the actual erosion rate was obtained. It was also the municipality with the highest calculated C-factor, due to the high share of black fallows. 


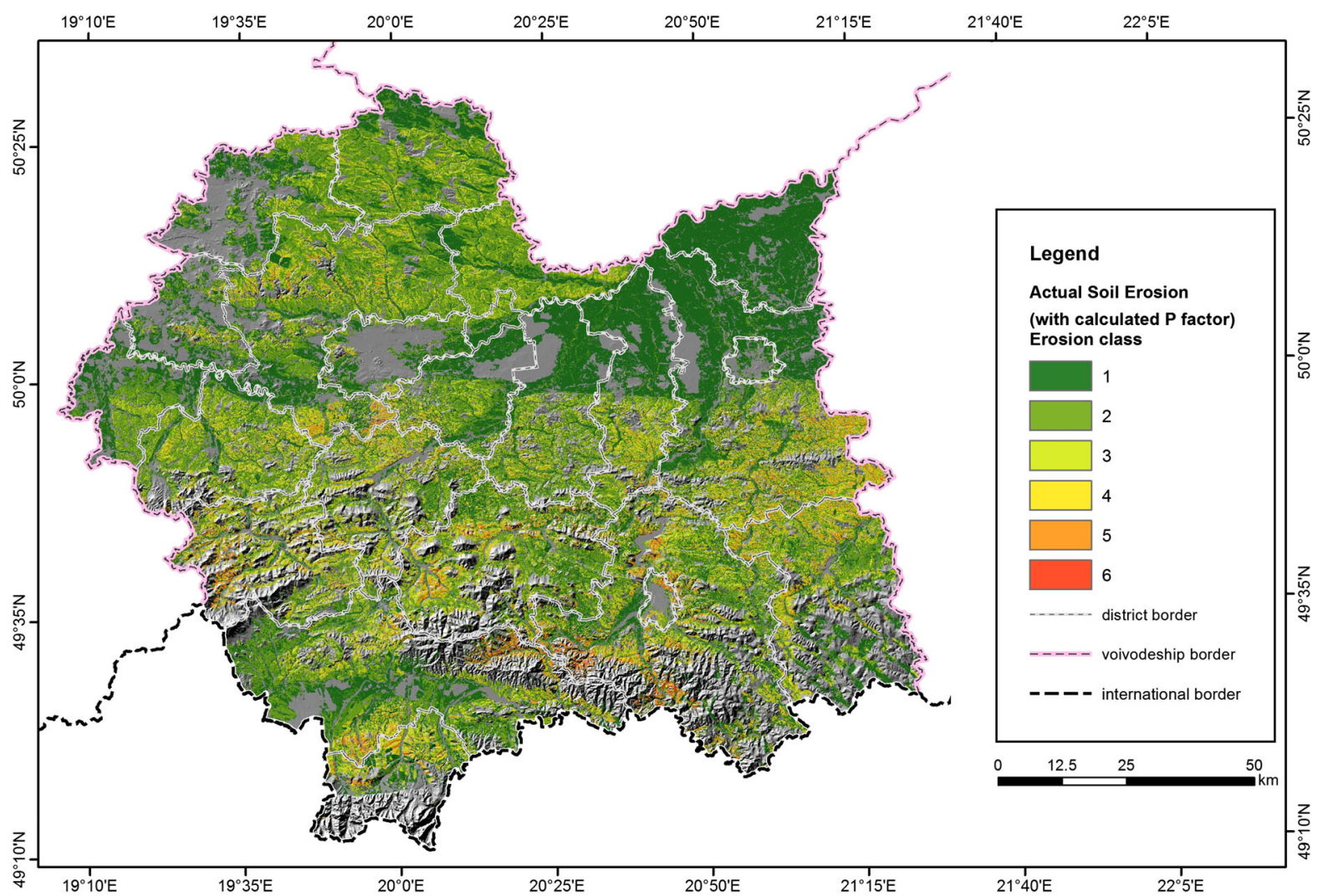

Figure 15

Actual soil erosion risk-qualitative assessment

Table 6

A summary of potential soil erosion statistics

\begin{tabular}{llcc}
\hline Potential erosion class & Class description & Total area of erosion class [ha] & $\begin{array}{l}\text { Percentage of erosion class } \\
\text { in agricultural land [\%] }\end{array}$ \\
\hline 1 & No erosion & $108,164.34$ & 15.62 \\
2 & Low erosion & $165,989.25$ & 23.97 \\
3 & Moderate erosion & $219,998.25$ & 31.77 \\
4 & Medium erosion & $105,621.75$ & 15.25 \\
5 & Strong erosion & $82,644.75$ & 11.93 \\
6 & Very strong erosion & $10,067.94$ & 1.45 \\
\hline
\end{tabular}

Table 7

A summary of actual soil erosion statistics

\begin{tabular}{llrr}
\hline Actual erosion class & Class description & Total area of erosion class [ha] & $\begin{array}{r}\text { Percent of erosion class } \\
\text { in agricultural land [\%] }\end{array}$ \\
\hline 1 & No erosion & $279,880.22$ & 40.39 \\
2 & Low erosion & $226,175.33$ & 32.64 \\
3 & Moderate erosion & $113,736.56$ & 16.41 \\
4 & Average erosion & $45,553.16$ & 6.57 \\
5 & Strong erosion & $26,047.44$ & 3.76 \\
6 & Very strong erosion & $1,589.02$ & 0.23 \\
\hline
\end{tabular}




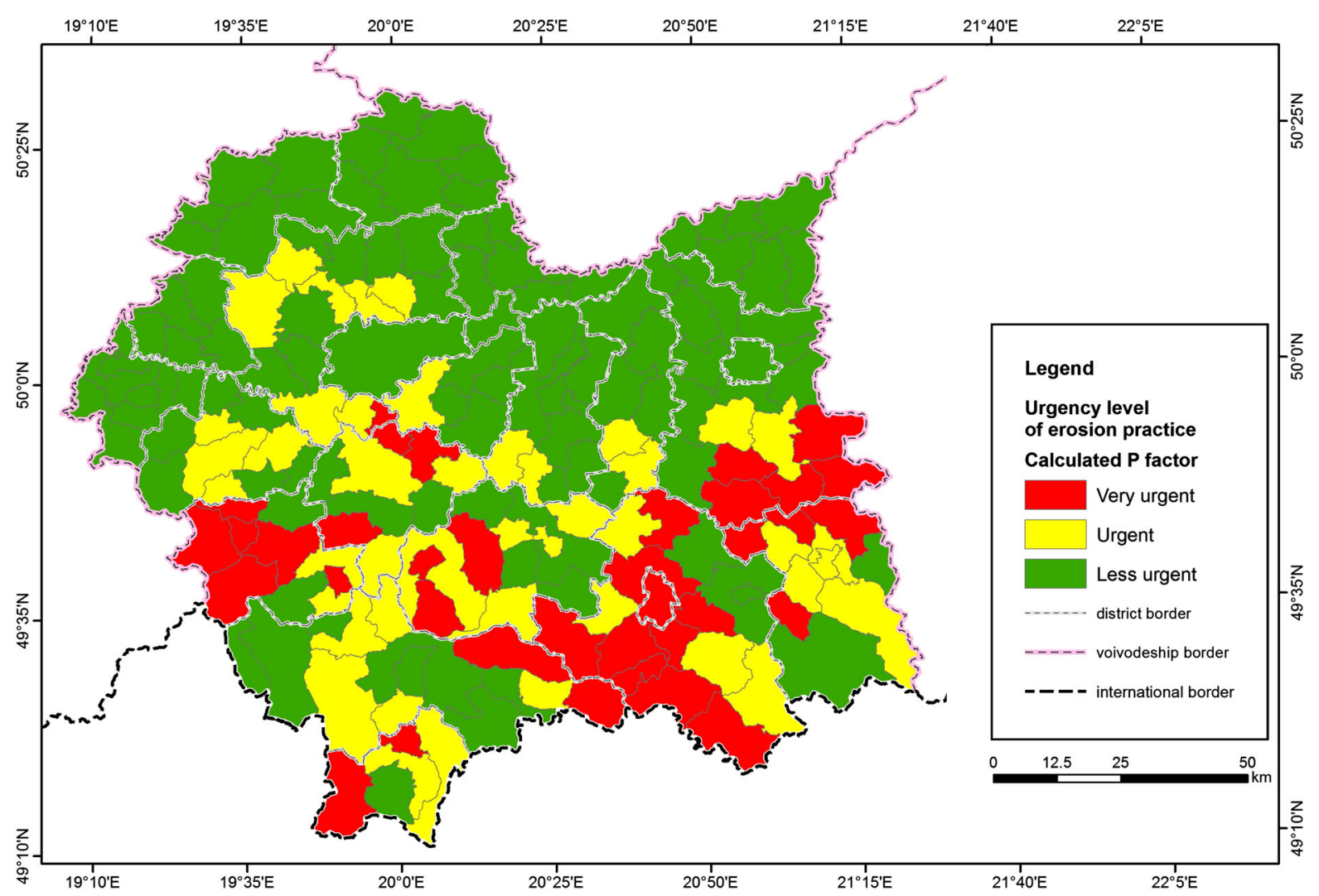

Figure 16

Urgency level of erosion control practice-municipalities of the Małopolska Voivodeship

Table 8

Actual soil erosion summary statistics calculated when $P=1$

\begin{tabular}{llll}
\hline $\begin{array}{l}\text { Actual } \\
\text { Erosion class }\end{array}$ & Class description & Total area of erosion class [ha] & $\begin{array}{l}\text { Percentage of erosion class } \\
\text { on agricultural land [\%] }\end{array}$ \\
\hline 1 & No erosion & $276,497.71$ & 39.90 \\
2 & Low erosion & $221,761.89$ & 32.00 \\
3 & Moderate erosion & $117,264.51$ & 16.92 \\
4 & Average erosion & $48,333.89$ & 6.97 \\
5 & Strong erosion & $27,517.01$ & 3.97 \\
\hline
\end{tabular}

The results presented are inevitably associated with some level of uncertainty induced by the model structure, adopted methods of USLE factors, and the evaluation and uncertainty of input data. However, the input data used for this study is the best data available on a regional scale in Małopolska. Obviously, the disaggregation of data about areas sown with particular crops from the voivodeship to the municipality level introduces substantial uncertainty to calculated $\mathrm{C}$-factor values. The assumption about the uniformity of changes in the acreage of crops in the voivodeship is an obvious simplification. However, a lack of information regarding their spatial distribution caused this necessity. On the other hand, in the light of land use changes which took place between 2002 and 2010, calculation of crop and 


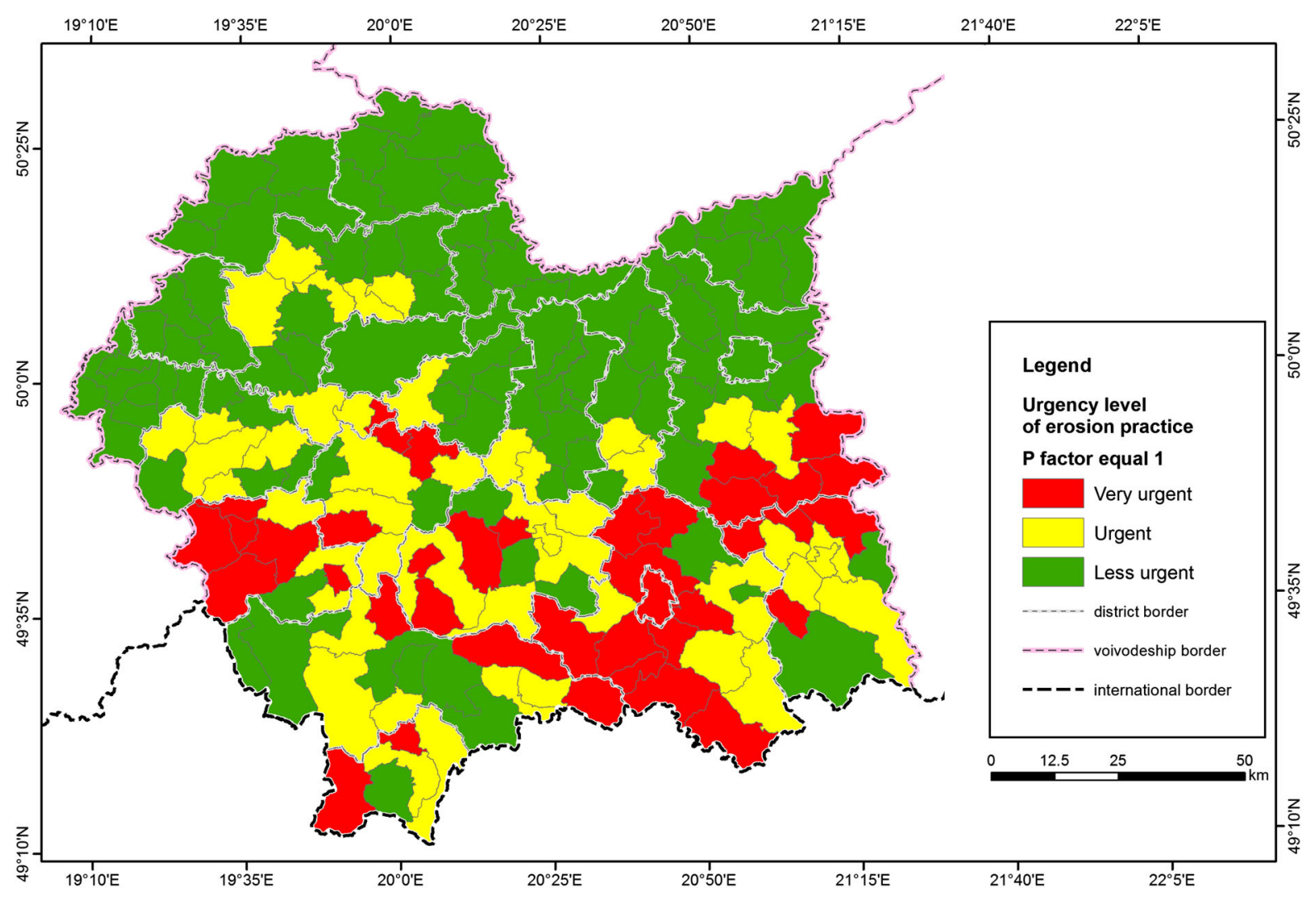

Figure 17

Urgency level of the erosion control practice (calculated when the P-factor value equals 1)—municipalities of the Małopolska Voivodeship

management factor values based on 2002 data would introduce uncertainties as well, especially when changes in black fallow and green fallow lands are considered. Because of these changes, the approach based on data disaggregation was selected as the more appropriate one for the assessment of actual erosion risk. Nevertheless, it is strongly advised to repeat the erosion risk assessment when data from the last National Agricultural Census becomes available at the municipality level.

To improve the quality of erosion modeling results, the methods of estimation of USLE factor values should also be improved. Satellite remote sensing technology may be seen as a helpful tool in this task. By using VHRS sensors with spatial resolutions (GSD) better then $1.0 \mathrm{~m}(\mathrm{PAN})$, theoretically, the quality of the OBIA analysis for an update of LULC classes should be higher. On the other hand, the size of the processed images will be $\times 25$ bigger in relation to the RapidEye sensor used in this work.
This is a very significant technical challenge requiring a large investment in hardware and software. Increasing the spectral resolution of the planned new sensors (like EnMap-244 spectral bands) may also contribute to the improvement of the classification results as already in the case of the WorldView-2 satellite (8 spectral bands incl. 2 NIR and 1 Red Edge). Reliable field-level identification of crops would increase the quality of actual erosion assessment as C-factor values could be assigned to particular fields or land parcels.

The satellite remote sensing technology and the OBIA approach gave valuable support to this study, not only because reliable LULC mapping and improved C-factor estimation. The application of OBIA also led to defining the direction of field cultivation and the mapping of contour tillage areas. It was possible as we assumed that the long but rather narrow plots of land typical for the Małopolska region are ploughed along their longer edge. Such an 
approach may not be possible in other areas, but other applications of OBIA and high-resolution satellite images for the detection and mapping of erosion control practices (TINDALl et al. 2008; KARYDAS et al. 2009) are also encouraging. Our study showed that even a slight improvement of P-factor estimation may have an influence on modeling results. In our case, despite a marginal change of erosion assessment figures on a regional scale, the influence on the final prioritization of areas according to erosion control needs is visible. These findings support the conclusion by KARYDAS et al. (2009) that high-resolution satellite imagery may be efficiently used for P-factor mapping and thus contribute to a refined soil erosion risk assessment.

In our opinion, in the near future, an increased accuracy of the LS-factor can be achieved as well, through the implementation of new RS systems such as satellite radar sensors: TeraSar-X and Tandem-X, which soon will provide a new quality of geo-data called high-resolution terrain information (HRTI) DEM. The authors also see an additional opportunity to strengthen soil erosion modeling using the OBIA approach. LiDAR technology offers even more precise data on both the DTM (LS-factor) and DSM (C- and P-factors). The correctness of satellite imagery classification can be improved by using $3 \mathrm{D}$ point clouds from airborne laser scanning. In the near future, in the frame of the ISOK project, ALS point clouds, highly-precise elevation models (DTM, DSM); aerial photographs; and aerial orthophotos, will cover almost $60 \%$ of Poland. The data will meet the very high standards, namely density (standard I: 4 points $/ \mathrm{m}^{2}$, Standard II: $12 \mathrm{pkt} / \mathrm{m}^{2}$ ) when registering at least four echos, the intensity, classification or RGB attributes (assigned from aerial photographs) will be a very valuable source of geodata (WË̇̀K et al. 2012).

To sum up, the satellite remote sensing technology was an asset to successfully and efficiently completing the project. Both, the potential and the actual soil erosion risks were assessed quantitatively and qualitatively. The obtained results were added to the digital spatial soil map database and presented in map form on a scale of 1:10,000. The study was presented in reports prepared for the entire area of the Małopolska Voivodeship. Additionally, each administrative unit also obtained recommendations about soil erosion reduction in priority areas, and the measures tailored to its environmental conditions.

Open Access This article is distributed under the terms of the Creative Commons Attribution License which permits any use, distribution, and reproduction in any medium, provided the original author(s) and the source are credited.

\section{REFERENCES}

AldRed D., WANG J., 2011. A method for obtaining and applying classification parameters in object-based urban rooftop extraction from VHR multispectral images. International Journal of Remote Sensing, Volume 32, Issue 10, p. 2811-2823.

Arnoldus H.M.J., 1977. Methodology used to determine the maximum potential average annual soil loss due to sheet and rill erosion in Morocco [in:] Assessing Soil Degradation. FAO Soils Bulletin 34, Rome.

Benz U. C., Hofmann P., Willhauck G., Lingenfelder I., Heynen M., 2004. Multi resolution, object-oriented fuzzy analysis of remote sensing data for GIS-ready information. ISPRS Journal of Photogrammetry \& Remote Sensing, 58, pp. 239-258.

BlaschKe, T., 2010. Object based image analysis for remote sensing. ISPRS Journal of Photogrammetry and Remote Sensing 65(1), 2-16.

Bork H.-R., 2003. State-of-the-art of erosion research - soil erosion and its consequences since 1800 AD. In: Briefing Papers of the first SCAPE workshop in Alicante (ES), 14-16 June 2003.

Cebecauer Y., Hofierka J., 2008. The consequences of land-cover changes on soil erosion distribution in Slovakia. Geomorphology, 98, 187-198.

Chen T., Niu R., Li P., Zhang L., Du B., 2011. Regional soil erosion risk mapping using RUSLE, GIS, and remote sensing: a case study in Miyun Watershed, North China. Environmental Earth Sciences, 63, 3, 533-541.

Coutinho M.A., Tomas P.P., 1995. Comparison of Fournier with Wischmeier rainfall erosivity indexes [w:] Proceedings First International Congress, European Society for Soil Conservation (ESSC), Silsoe. CAB International.

DE KoK R., WĖ̇YK P., 2008. Principles of full autonomy in image interpretation. The basic architectural design for a sequential process with image objects. In: Object-Based Image Analysis. Blaschke Th., Lang S., Hay G.J. (Eds.). Series: Lecture Notes in Geoinformation and Cartography. Springer Berlin Heidelberg. p. 697-710.

Desmet P.J., Govers G., 1996. A GIS procedure for automatically calculating the USLE LS factor on topographically complex landscape units. Journal of Soil and Water Conservation, 51, 5, 427-433.

Deumlich D., Kiesel J., Thiere J., Reuter H. I., Völker L, Funk R., 2006. Application of the SIte COmparison Method (SICOM) to assess the potential erosion risk-a basis for the evaluation of spatial equivalence of agri-environmental measures. Catena, 68 , $141-152$.

Dobrzański B., Gliński J., Guz T., Pomian J., 1962. Charakterystyka erodowanych gleb dorzecza Czarnej Wody. Roczniki Nauk Rolniczych t. 96, seria D, 63-92. 
DRZEWIECKI W., 2008. Sustainable land-use planning support by GIS-based evaluation of landscape functions and potentials. The International Archives of the Photogrammetry, Remote Sensing and Spatial Information Sciences, vol. 37, B7, 1497-1502. Erhard M., Böken H., Glante F., 2003. The Assessment of the Actual Soil Erosion Risk in Germany, Based on CORINE LandCover and Statistical Data from the Main Representative Survey of Land Use. In: Agricultural Impacts on Soil Erosion and Soil Biodiversity: Developing Indicators for Policy Analysis (Ed. R. Francaviglia). Proceedings from an OECD Expert Meeting, Rome, Italy, March 2003, 253-262.

Foster G.R., WischMEIER W.H., 1974. Evaluating irregular slopes for soil loss prediction. Transactions of ASAE, 17, 2, 305-309.

GoOvAERTS P., 1999. Using elevation to aid the geostatistical mapping of rainfall erosivity. Catena, 34, 227-242.

GugIK, 2008. Wytyczne techniczne. Baza Danych Topograficznych (TBD). Wersja 1 uzupełniona. Warszawa 2008.

JeloneK J., WycZAłEK I., 2006. Automatyczna detekcja zmian urbanistycznych na zdjeciach lotniczych. Archiwum Fotogrametrii i Teledetekcji, Vol.16, 249-257.

Jones R. J. A., Le Bissonnais Y., Bazzoffi P., Sánchez Diaz J., LoJ G., Øygarden L., Prasuhn V., Rydell B., Strauss P., Berényi Üveges J., Vandekerckhove L., Yordanov Y., 2004. Nature and Extent of Soil Erosion in Europe. In: Reports of the Technical Working Groups Established under the Thematic Strategy for Soil Protection, Vol. II, Erosion (Eds.: L. VAN-CAMP, B. BUJARRABAL, A. R. Gentile, R. J. A. Jones, L. Montanarella, C. Olazabal, S.-K. SELVARADJOU). EUR 21319 EN/2, Office for Official Publications of the European Communities, Luxembourg.

Józefaciuk, A., Józefaciuk, Cz., 1992. Zagrożenie erozja wodna w Polsce. Pamietnik Puławski, 101 supl., 23-50.

JózEFACiUK A., JózefaCiuk Cz., 1996. Mechanizm i wskazówki metodyczne badania procesów erozji. Biblioteka Monitoringu Środowiska, PIOŚ, Warszawa.

Józefaciuk C., Józefaciuk A., 1975. Komentarz do instrukcji w sprawie inwentaryzacji gruntów zagrożonych erozja. IUNG, Puławy.

Karydas C. G., Sekuloska T., Silleos G. N., (2009) Quantification and site-specification of the support practice factor when mapping soil erosion risk associated with olive plantations in the Mediterranean island of Crete. Environmental Monitoring and Assessment, 149, 19-28.

Kirkby, M.J., Jones, R.J.A., Irvine, B., Gobin, A, Govers, G., Cerdan, O., Van Rompaey, A.J.J., Le Bissonnais, Y., Daroussin, J., King, D., Montanarella, L., Grimm, M., Vieillefont, V., Puigdefabregas, J., Boer, M., Kosmas, C., Yassoglou, N., Tsara, M., Mantel, S., Van Lynden, G.J. and Huting, J. (2004). Pan-European Soil Erosion Risk Assessment: The PESERA Map, Version 1 October 2003. Explanation of Special Publication Ispra 2004 No.73 (S.P.I.04.73). European Soil Bureau Research Report No.16, EUR 21176, 18 pp. and 1 map in ISO B1 format. Office for Official Publications of the European Communities, Luxembourg.

Kolasa M., 1961. Geotechniczne właściwości lessów okolicy Krakowa. Rozprawa doktorska. Katedra Złóż Surowców Skalnych, AGH w Krakowie.

KOMORNICKI T. 1958. Gleba “cerkla wzorcowego" w Jaworkach k/Szczawnicy. Roczniki Nauk Rolniczych t. 72, 3, seria F, 993-1014.

KoReleski K., 1992. Próby oceny natężenia erozji wodnej. Zeszyty Naukowe Akademii Rolniczej im. H. Kołtataja w Krakowie, Sesja Naukowa, z. 35, 91-100.
KORELESKI K., 2005. Wybrane zagadnienia przeciwerozyjnej ochrony gleb $w$ świetle wymogów zrównoważonego rozwoju. Acta Agrophisica, 5, 1, 49-55.

KozaK J., 2003. Forest cover changes in the Western Carpathians over the past 180 years: a case study from the Orawa region in Poland. Mountain Research and Development, Vol. 23, 369-375.

KrischKe M., Niemeyer W., SCherer S., 2000. RapidEye satellite based geo-information system. Acta Astronautica, Vol. 46, 307-312.

Laflen J. M., Roose E. J., 1998. Methodologies for Assessement of Soil Degradation Due to Water Erosion. In: Methods for Assessement of Soil Degradation (Eds. R. LAI, W. H. BLUM, C. VAlentine, B. A. STEWART). Advances in Soil Science, CRC Press, Boca Raton, New York.

LiczNAR P, 2003. Modelowanie erozji wodnej gleb. Zeszyty naukowe Akademii Rolniczej we Wrocławiu nr 456, Monografie XXXII.

Licznar P., 2004. Prognozowanie erozyjności deszczy w Polsce na podstawie miesiecznych sum opadów. Archiwum Ochrony Środowiska, Vol. 30, 4, 29-39.

LicZNAR P., 2006. Artificial neural networks aided annual rainfall erosivity factor values calculation in Poland. Bonn, Gesellschaft fur Informatik, Land- und Ernahrungswirtschaft im Wandel Aufgaben und Herausforderungen fur die Agrar und Umweltinformatik, Referate der 26. GIL Jahrestagung, 06.-08. Marz 2006, Potsdam: $145-148$.

Lillesand, T.M., Kiefer, R.W., W.Chipman, J., 2007. Remote Sensing And Image Interpretation, 5th ed. Wiley India Pvt Ltd.

Martín-Fernández L., MartíneZ-NúŇEZ M., 2011. An empirical approach to estimate soil erosion risk in Spain. Science of the Total Environment, 409, 3114-3123.

Mitasova H., Hofierka J., Zlocha M., Iverson R. L., 1996. Modeling topographic potential for erosion and deposition using GIS. International Journal of Geographic Information Science, $10,5,629-641$.

Moore I.D., Burch G.J., 1986. Physical basis of the length-slope factor in the Universal Soil Loss Equation. Soil Science Society Journal, 50, 5, 1294-1298.

MoORE I.D., WILSON J.P., 1992. Length-slope factors for the Revised Universal Soil Loss Equation: Simplified method of estimation. Journal of Soil and Water Conservation, 47, 5, 423-428.

Park S., OH C., Jeon S., Jung H., Choi C., 2011. Soil erosion risk in Korean watersheds, assessed using the revised universal soil loss equation. Journal of Hydrology, 399, 263-273.

Prasannakumar V., Vijith H., Geetha N., Shiny R., 2011. Regional Scale Erosion Assessment of a Sub-tropical Highland Segment in the Western Ghats of Kerala, South India. Water Resource management, 25, 3715-3727.

Prasuhn V., Liniger H., Gisler S., Herweg K., Candinas A., Clément J.P., 2013. A high-resolution soil erosion risk map of Switzerland as strategic policy support system. Land Use Policy, 32, 281-291.

Renard K. G., Foster G. R., Weesies G. A., McCool D. K., Yoder D. C., 1997. Predicting Soil Erosion by Water: A Guide to Conservation Planning With the Revised Universal Soil Loss Equation (RUSLE). U.S. Department of Agriculture, Agriculture Handbook No. 703.

Renard K. G., Freimund J. R., 1994. Using monthly precipitation data to estimate $R$-factor in the revised USLE. Journal of Hydrology, 157, 287-306. 
Sandau R., Brieß K., D’Errico M., 2010. Small satellites for global coverage: Potential limits. ISPRS Journal of Photogrammetry and Remote Sensing, 65, 92-504.

SCHMIDT R.-G., 1989. Erosionswiderstandsfunktion [in:] MARKS R., Muller M.J., LeSer H., KLINK H.-J. (Eds.): Anleitung zur Bewertung des Leistungsvermogens des Landschaftshaushaltes (BA LVL). Forschungen zur Deutschen Landeskunde Band 229, ZentralaussufŔ fur deutsche Landeskunde, Selbstverlag, Trier.

Stuczyński T., KoZa P.,ŁopatKa A., DuER I., JadCZyszsyn J., 2010. Raport $z$ analizy wskaźników produktu, rezultatu i oddziaływania określonych dla osi 2 PROW 2007-2013 oraz wybranych pytań oceniajacych zawartych $w$ podrecczniku wspólnych ram monitorowania i oceny. Wytyczne (CMEF) wraz z określeniem źródet $i$ dostepności danych. IUNG-PIB, Puławy. www.minrol.gov.pl/ pol/content/download/28450/158380/file/Rap_z_analizy_wskazn ikow.pdf.

Šúri M., Cebecauer T., Hofierka J., Fulajtár E., 2002. Soil Erosion Assessment of Slovakia at a Regional Scale Using GIS. Ecology (Bratislava), 21, 4, 404-422.

Terranova O., Antronico L., Coscarelli R., Iaquinta P., 2009. Soil erosion risk scenarios in the Mediterranean environment using RUSLE and GIS: An application model for Calabria (southern Italy). Geomorphology, 112, 228-245.

Tetzlaff B., Friedrich K., Vorderbrügge T., Vereecken H., Wendland F., 2013. Distributed modelling of mean annual soil erosion and sediment delivery rates to surface waters. Catena, 102, 13-20.

Tindall D., Denham R., Witte C., Carey B., 2008. Development and application of remote sensing techniques for detecting and mapping a land management practice: contour banks. The State of Queensland, Department of Natural Resources and Water, Brisbane.

URBAŃSKI K., 2008. Metodyka dokumentowania chemicznych przeksztatceń gleb na terenach przemystowych. Rozprawa doktorska. Katedra Kształtowania i Ochrony Środowiska, AGH w Krakowie.

VAN LyNDEN G.W.J., 1995. European soil resources. Nature and Environment No. 71. Council of Europe, Strasbourg.
VRIELING A., 2006. Satellite remote sensing for water erosion assessment: A review. Catena, 65, 2-18.

WARD A.D., ElLIOT W.J., 1995. Environmental Hydrology. CRC Press, Lewis Publishers, Boca Raton, New York, London, Tokyo.

WAwER R., 2007. Erozja wodna aktualna $w$ Polsce wg województw w oparciu o Corine CLC2000. Inżynieria Ekologiczna, 18, 104-105.

WAWER R., NowoCIEŃ E., 2006. Cyfrowa mapa występowania erozji wodnej powierzchniowej obszaru Polski z wykorzystaniem CORINE Land Cover 2000. Rozdzielczość przestrzenna $500 \mathrm{~m}$. Roczniki Akademii Rolniczej w Poznaniu, CCCLXXV, Rolnictwo 65, 207-213.

Wawer R., Nowocień E., 2007. Digital Map of Water Erosion Risk in Poland: A Qualitative, Vector-Based Approach. Polish Journal of Environmental Studies, Vol. 16, No 5, 763-772.

Wawer R., Nowocień E., Budzyńska K., Kozyra J., 2006. Cyfrowa mapa zagrożenia erozja wodna powierzchniowa obszaru Polski, rozdzielczość przestrzenna $500 \mathrm{~m}$. Roczniki Akademii Rolniczej w Poznaniu, CCCLXXV, Rolnictwo 65, 215-221.

Wawer R., Nowocień E., Podolski B., 2005. Real and Calculated K USLE Erodibility Factor for Selected Polish Soils, Polish Journal of Environmental Studies, Vol. 14, No 5 : 655-658.

Wężyk P., Mlost J., Pierzchalski M., Wóttowicz-Nowakowska A., Szwed P., 2012 Enhancing the OBIA classification of multispectral aerial orthoimages using Airborne Laser Scanning data. Archive of Photogrammetry, Cartography and Remote Sensing, 23, 467-476.

Winchell M.F., Jackson S.H., Wadley A.M., SRinivasan R., 2008. Extension and validation of geographic information systembased method for calculating the Revised Soil Loss Equation length-slope factor for erosion risk assessments in large watersheds. Journal of Soil and Water Conservation, 63, 3, 105-111.

WischmeIER W. H., SMith D.D., 1978. Predicting Rainfall Erosion Losses - A Guide to Conservation Planning. USDA Handbook 537, Washington, D. C.

Zhang W., Zhang Z., Liu F., Qiao Z, Hu S., 2011. Estimation of the USLE Cover and Management Factor C Using Satellite Remote Sensing: a Review. IEEE Conference Publications, 19th International Conference on Geoinformatics, pp. 1-5. 